\title{
The Santorini-Amorgos Shear Zone: Evidence for Dextral Transtension in the South Aegean Back-Arc Region, Greece
}

\author{
Konstantina Tsampouraki-Kraounaki ${ }^{1,2, * D}$, Dimitris Sakellariou ${ }^{1}$, Grigoris Rousakis ${ }^{1}$, Ioannis Morfis ${ }^{1}$, \\ Ioannis Panagiotopoulos ${ }^{1}\left(\mathbb{D}\right.$, Isidoros Livanos ${ }^{1}$, Kyriaki Manta ${ }^{1,2}$ (D), Fratzeska Paraschos ${ }^{1,2}$ (D) \\ and George Papatheodorou 2 (D) \\ 1 Institute of Oceanography, Hellenic Center for Marine Research, 19013 Anavyssos, Greece; \\ sakell@hcmr.gr (D.S.); rousakis@hcmr.gr (G.R.); gianmor@hcmr.gr (I.M.); jpanagiot@hcmr.gr (I.P.); \\ ilivanos@hcmr.gr (I.L.); kmanta@hcmr.gr (K.M.); fparaskos@hcmr.gr (F.P.) \\ 2 Department of Geology, University of Patras, 26504 Rio, Greece; gpapathe@upatras.gr \\ * Correspondence: tsampourakik@hcmr.gr
}

Citation: Tsampouraki-Kraounaki, K.; Sakellariou, D.; Rousakis, G.; Morfis, I.; Panagiotopoulos, I.; Livanos, I.; Manta, K.; Paraschos, F.; Papatheodorou, G. The Santorini-Amorgos Shear Zone: Evidence for Dextral Transtension in the South Aegean Back-Arc Region, Greece. Geosciences 2021, 11, 216. https://doi.org/10.3390/ geosciences 11050216

Academic Editors: Jesus MartinezFrias, Ioannis Kassaras, Athanassios Ganas and Paolo Pace

\section{Received: 21 April 2021}

Accepted: 12 May 2021

Published: 14 May 2021

Publisher's Note: MDPI stays neutral with regard to jurisdictional claims in published maps and institutional affiliations.

Copyright: (c) 2021 by the authors. Licensee MDPI, Basel, Switzerland. This article is an open access article distributed under the terms and conditions of the Creative Commons Attribution (CC BY) license (https:// creativecommons.org/licenses/by/ $4.0 /)$.

\begin{abstract}
Bathymetric and seismic data provide insights into the geomorphological configuration, seismic stratigraphy, structure, and evolution of the area between Santorini, Amorgos, Astypalea, and Anafi islands. Santorini-Amorgos Shear Zone (SASZ) is a NE-SW striking feature that includes seven basins, two shallow ridges, and hosts the volcanic centers of Santorini and Kolumbo. The SASZ initiated in the Early Pliocene as a single, W-E oriented basin. A major reorganization of the geodynamic regime led to (i) reorientation of the older faults and initiation of NE-SW striking ones, (ii) disruption of the single basin and localized subsidence and uplift, (iii) creation of four basins out of the former single one (Anafi, Amorgos South, Amorgos North, and Kinairos basins), (iv) rifting of the northern and southern margins and creation of Anydros, Astypalea North, and Astypalea South basins, and (v) uplift of the ridges. Dextral shearing and oblique rifting are accommodated by NE-SW striking, dextral oblique to strike-slip faults and by roughly W-E striking, normal, transfer faults. It is suggested here that enhanced shearing in NE-SW direction and oblique rifting may be the dominant deformation mechanism in the South Aegean since Early Quaternary associated with the interaction of North Anatolian Fault with the slab roll-back.
\end{abstract}

Keywords: back arc deformation; Santorini; Amorgos; basin evolution; dextral shearing; oblique rifting

\section{Introduction}

The Aegean back-arc domain displays a complicated, not yet fully understood, tectonic structure and has been developed on the southern edge of the overriding Eurasian plate, above the northward subducting slab of the East Mediterranean crust. The tectonic setting and the active deformation render the Aegean as a key area for the understanding of back-arc deformation processes. The post-Miocene history of the Aegean is characterized by back-arc extension already initiated in the Eocene [1,2] (and references therein) and by the westward motion of Anatolia expressed through the dextral, strike-slip North Anatolian Fault (NAF) [3-5] (and references therein). Several hypotheses have been proposed about the evolution of the complex deformation of the Aegean [6-10]. Seismological and geological studies [3,4,11-23] and GPS surveys [5,24-41] have tried to define and explain the kinematic setting in the Aegean. However, comprehensive evidence on the geological evolution and the strain localization in the Aegean has not yet been revealed because there are still many areas that have either not been surveyed or have been with insufficient data [42].

The Aegean domain is characterized by Mascle and Martin [43] as a deforming microplate bounded to the north by the dextral North Anatolian Fault and to the south by the sinistral fault zones of Strabo and Pliny Trenches (Figure 1). The deformation in the 
northern part is mainly controlled by NE-SW trending strike-slip faulting [42]. The active tectonic framework of the North Aegean, derived from geological and geophysical data and earthquake focal mechanisms, indicates a typical right-lateral strike-slip faulting regime $[16,21,44]$ along the North Anatolian Fault and its southern branches. GPS data confirm the strike-slip motion across the NAF to about $23 \mathrm{~mm} /$ year $[5,33,35-39,45]$. The central and western parts of the South Aegean Sea behave more or less like a rigid body, according to the kinematic model proposed by Kreemer and Chamot-Rooke [36]. These authors suggest that the backstop of the Mediterranean Ridge (Figure 1) and the southern Aegean block exhibit insignificant internal deformation and move with 33-34 mm/year in the direction of $\mathrm{S} 24^{\circ} \mathrm{W} \pm 1^{\circ}$ towards stable Africa, while the southeastern Aegean moves moderately fast in an SSE direction, away from the rigid South Aegean $[21,35,36,46]$ and (references therein).

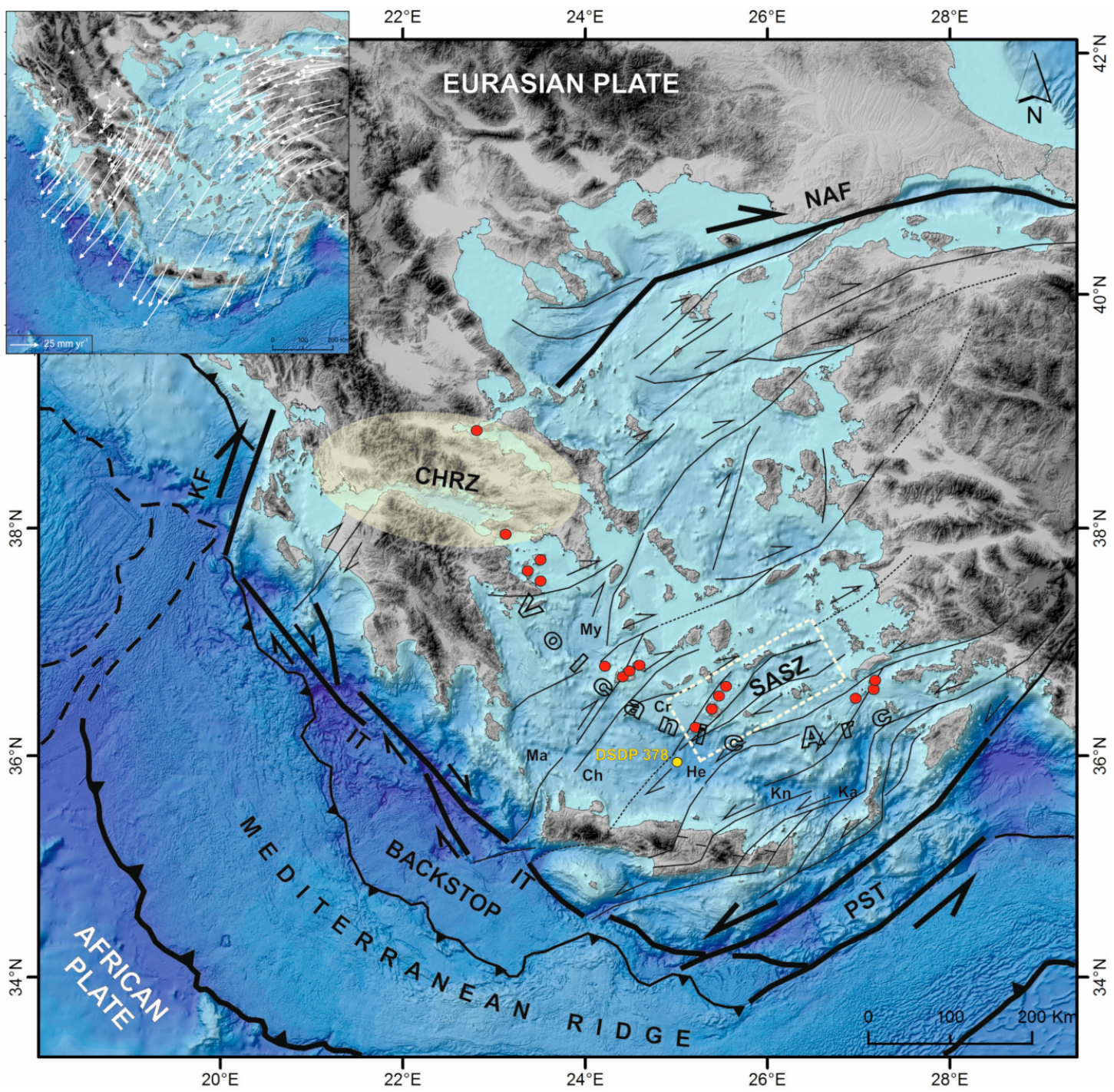

Figure 1. Major geodynamic elements of the broader Aegean Region, modified after Sakellariou and Tsampouraki-Kraounaki (Dimitriadis, I.; et al. 2009). The white parallelogram delineates the study area. Red dots represent the volcanoes on the Hellenic Volcanic Arc. NAF: North Anatolian Fault, KF: Kephallinia Fault, IT: Ionian Trench, PSF: Pliny-Strabo Trenches, CHRZ: Central Hellenic Relay Zone, SASZ: Santorini-Amorgos Shear Zone. Basins: Cr: Christiana, He: Heraklion, Ka: Karpathos, Kn: Kamilonissi, Ma: Maleas, My: Myrtoon.

Although it is widely accepted that the geotectonic evolution of the Aegean microplate is dominated by extension in a back-arc setting, recent geological, seismological and 
geodetic studies have shown that overall extension may evolve in combination with transpression or transtention [47] (and references therein). The uniqueness of this complex deformation developed in an active plate boundary zone, between two almost parallel but with opposite sense of movement strike-slip zones, demonstrates the distinctiveness of the area and explains the existence of multiple different kinematic models proposed so far (Figure 1). The style of deformation and kinematics changes from North to South across the Aegean. Dextral strike-slip tectonics along NE-SW major fault zones dominates in the North Aegean and as far south as the North Ikarian Basin [21]. Sakellariou and Tsampouraki-Kraounaki [42] propose that dextral-strike slip faulting prevails further to the South, with the Santorini-Amorgos (SA) Fault Zone being the last one towards the south, that displays a dextral sense of motion. This is in agreement with the results of the micro-seismicity research of Bohnhoff et al. [48], who suggest right-lateral transtension along the SW-NE Santorini (Thera)-Amorgos zone with the direction of extension being NW-SE. They also propose that Santorini-Amorgos Zone is a major structural boundary of the Hellenic Volcanic Arc which is characterized by crustal weakness and divides the seismically and volcanically more active eastern part from the quiet western part.

The same area seems to be a transition zone between the northern and southern Aegean, as the change from dextral to sinistral sense of shear seems to occur south of the Santorini-Amorgos Fault Zone. Pe-Piper et al. [49] related the volcanism at Kos and Nisyros islands with sinistral ENE-WSW trending strike-slip faults. Furthermore, recent studies of Uluğ et al. [50] and Işcan et al. [51] have shown that the Gulf of Gökova (GG), east of the island of Kos, undergoes deformation related to strike-slip tectonics. Ocakoğlu et al. [52] also mapped a left-lateral NE-SW strike-slip fault zone with segments crossing the Gökova Gulf from its northern part to south of Kos. Tur et al. [47] interpreted this area as part of a lazy-S shaped structure which includes the Kamilonisi Basin (KaB), the South and North Karpathos Basins (SK and NK), and the Gulf of Gökova. The aforementioned literature data verify the suggestion of Mascle and Martin [43] according to which, NE-SW trending shear zones control the Plio-Quaternary evolution of the Aegean. Further on, they support the observations of Sakellariou and Tsampouraki-Kraounaki [42] on the change of the sense of shear, from dextral to sinistral, across the Aegean. According to Sakellariou and Tsampouraki-Kraounaki [42], the Santorini-Amorgos Fault coincides with the southeastern boundary of the "rigid" Central Aegean Block with the deforming Southeast Aegean Block as defined by Reilinger et al. [5].

The present study focuses on the southeastern margin of the Central Aegean Sea (Figure 1), particularly in the area between Santorini, Amorgos, and Astypalea islands, referred to as Santorini-Amorgos Shear Zone (SASZ). The purpose of this study is divided into two main levels. The detailed mapping of the morphotectonic tissue of the area, through the presentation of the results concerning the seismic stratigraphy, the seabed morphology, and the dominant fault network of the area constitute the first level. The interpretation and understanding thereof, lead us to the second level and to the questions arising from its correlation with the deformation prevailing in the entire Aegean domain.

\section{Geological Setting}

\subsection{Regional Geological Setting}

The study area is bounded by the islands of Central and southeastern Aegean and, more specifically, by Santorini Island to the west, Amorgos Island and Kinairos and Levitha Islets to the north, and Anafi and Astypalea Islands to the south (Figure 2). Metamorphic, volcanic and Neogene-Quaternary sediments constitute those islands [53]. The central and western part of that area is described by Nomikou et al. [54] as the Santorini-Amorgos Tectonic Zone (SATZ). Alpine formations, separated by the system of Miocene extensional detachments, form the basement of the area. Metamorphic rocks of the Attico-Cycladic complex constitute Santorini's basement [55]. The metamorphic formations of the Atticocycladic massif (gneisses, schists, marbles, and limestones) covering the greatest part of the island of Amorgos and the eastern part of Anafi [56] show a different stratigraphy, 
related to the external shallow-water carbonate platform of the Hellenides [57,58]. According to Papadopoulos and Pavlides [59], Amorgos Island is constituted by rocks of the Triassic, post-Triassic-Eocene, and middle Eocene-Oligocene. Very few outcrops of Pleistocene and alluvial deposits can be found. The morphology of the Amorgos Island is the result of brittle deformation (mainly normal to right-lateral oblique-slip faults) [59] (and references therein). Non- or low-grade metamorphic rocks of Late Cretaceous age crop out on Anafi [60].
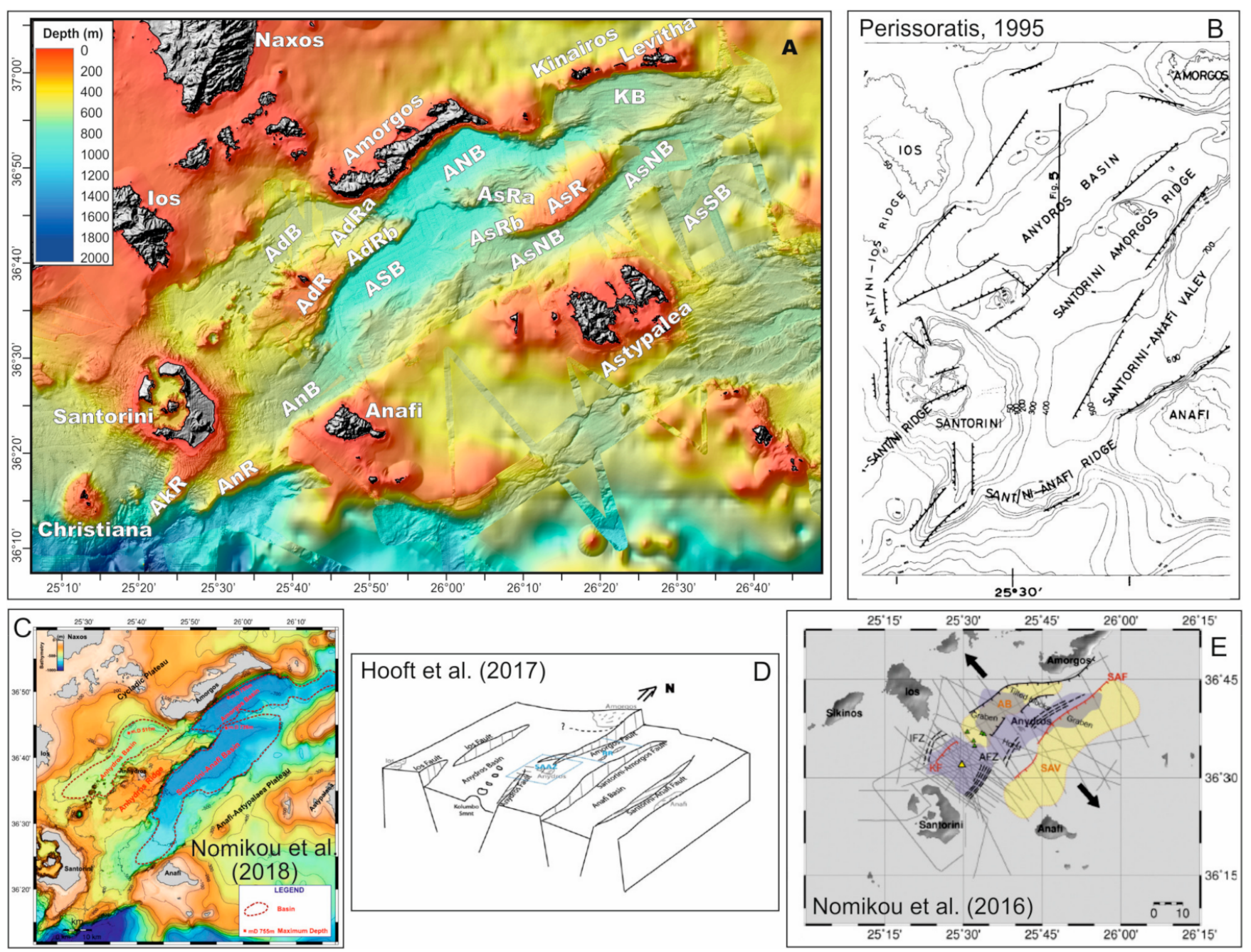

Figure 2. (A): Terminology of the main geomorphological elements used and discussed in the current work. AdB: Anydros Basin, AdR: Anydros Ridge, AnB: Anafi Basin, ANB: Amorgos North Basin, ASB: Amorgos South Basin, AsNB: Astypalea North Basin, AsSB: Astypalea South Basin, AsR: Astypalea Ridge, KB: Kinairos Basin. Bathymetry: 25 m resolution swath bathymetry superimposed on $100 \mathrm{~m}$ resolution EMODNET Bathymetry. (B-E): Terminology used by Perissoratis (1995), Nomikou et al. [54], (Hooft et al. 2017), and (Nomikou et al. 2016), respectively.

\subsection{Seismostratigraphy of the Area}

Several studies focusing on the seismic stratigraphy of the area, provide useful information on the sedimentary sequences deposited offshore. Perissoratis [61] mapped the main morphological features of the area between Santorini and the southwestern edge of Amorgos (Figure 2) and named them as Anydros Basin, Santorini-Amorgos Ridge, Santorini-Anafi Valley, and Santorini-Anafi Ridge. The same designations were also adopted by Nomikou et al. [62]. Afterwards, Hooft et al. [63] renamed Santorini-Anafi Valley to Anafi Basin, and, one year later, Nomikou et al. (2018) [54] expanded their field of research to the east (south of Amorgos Island) and recognized the existence of another 
basin, named as Amorgos Basin (Figure 2). The same study renamed the Anafi Basin to Santorini-Anafi Basin. The presentation of the results of the preexisting literature follows the naming of the morphological features as described in each work from which the specific results are taken.

Plio-Quaternary sediments of 600-700 m thickness maximum, intercalated with volcanoclastic material mainly in Anydros Basin, have been mapped in the offshore area $[61,62,64,65]$. Three distinct seismo-stratigraphic units referred to as A, B, and C (from top to bottom) are recognized and described by Perissoratis [61] within Anydros Basin and Santorini-Anafi Valley. Unit A is divided into two subunits, unit A1 and unit A2, by an erosional unconformity which is related to various sea-level changes that occurred during the Quaternary. Unit A1 shows high amplitude strong subparallel reflectors, while unit A2 displays a more regular and parallel seismic character. In some areas, subunit A1 lies conformably on A2, and it is not clearly distinguishable from A2 [66]. Syn-sedimentary faults mainly only affect subunit A2. Unit B is overlain unconformably by unit A2 (UR2) on ridges and on some basins and conformably in some basin areas [66]. Unit B is unconformably resting on unit $C$ showing strong and continuous reflectors, such as those in subunit A2, although its reflectors display higher amplitude. The unconformity between Unit A and Unit B coincides with the Pliocene/Quaternary boundary of the drilling results of Site 378 [67], indicating that Unit B is mainly of Pliocene age, while Unit A is assumed to be of Quaternary age [61]. According to Perissoratis [61], the lowermost parts of unit $\mathrm{B}$ were deposited as a basin filling facies during and after the formation of the basins. Unit $C$ marks the acoustic basement in the survey area and represents the alpine formations of the Atticocycladic Massif that crop out on the surrounding islands [61,62]. On the Santorini-Anafi Valley, Unit C can be mapped only in the shallow areas of the surrounding ridges. The Santorini-Amorgos Ridge is mainly formed by unit $\mathrm{C}$ that is locally covered by thin layers of sediments. Unit A is considered to be of Quaternary age, and unit B is mainly of Pliocene age [61]. Piper and Perissoratis [66], following the interpretation of the seismic stratigraphy of Perissoratis [61], named the unconformities within subunits A1-A2, and units B and C from top to bottom as UR1, UR2, and UR3 for the offshore area between the Santorini, Anafi, and Amorgos islands. UR1 is equivalent to the UK1 unconformity (west of Kalymnos) and the UN1 unconformity (between Kos and Nisyros). UN1 postdates the Kos Plateau Tuff that has a radiometric age of $161 \mathrm{ka}$ [68]. Based on a mean sedimentation rate of $0.1 \mathrm{~m} /$ kyear, the estimated age of UR3 is 150-190 ka [66].

Within the sedimentary sequence of Anydros Basin, six basin-fill units have been mapped, from AB-1 to AB-6, and are separated by unconformities ab-1 to ab-6 [54,62]. The same authors related units AB- 6 and AB- 5 with units A1 and A2 (volcanoclastics of Quaternary age) of Perissoratis [61] and unit AB-4 with unit B (terrestrial or shallow water sediments of Pliocene age). Hübscher et al. [65] related the five angular unconformities to rift pulses and suggested that they are associated with the five eruptive phases of the Kolumbo submarine volcano. Within the sedimentary sequence of Santorini-Anafi Basin (SAB), six different seismic units have been mapped and named from bottom to top as Sab-1 to Sab-6 [54], while Sab-0 corresponds to the acoustic basement. The interface between Sab-1 and Sab-0 displays a strong amplitude character with chaotic reflections beneath it. Nomikou et al. [54], recognized seismic units Amb-6 to Amb-3 as equivalents of the four upper units of Santorini-Anafi Basin and suggested that the Amorgos Basin is younger than $\mathrm{SAB}$ and $\mathrm{AB}$.

An attempt to define a chronological framework about the geodynamic evolution of the area was made by Nomikou et al. [54], based on the work of Hinsbergen et al. [69]. They suggested that the older parts of the sedimentary sequence (named as Units 1-3 on their study) are related with the initiation of the Aegean strike-slip system around 5.3-3.8 Ma, and the upper observed unconformities are related to the Rhodos tilting on 2.5-1.8 Ma and on 0.8 Ma. 


\subsection{Tectonic Setting}

Due to the complexity of the deformation in back-arc areas, the precise mechanisms dominating and affecting the formation of the main geomorphological features are not yet clear. The contradiction of the different theories, that have been suggested about the geodynamic processes that dominate the Aegean region and vary from the expected pure extension, that is customary to occur on back-arc zones, to more complex zones of transpresion and transtention [42], seems to be imprinted in the Santorini Amorgos Shear Zone, as well. Mascle and Martin [43] and Piper and Perissoratis [66] provided tectonic maps of the offshore faulting in the South Aegean Sea. Mascle and Martin [43] were the first to recognize NE-SW trending strike-slip faulting in the area. Papadopoulos and Pavlides [59] characterized the master neotectonic fault of Amorgos as an oblique-normal fault with a significant right-lateral strike-slip component and suggested that the tectonic picture of the area is more complex than the pure extension expected in back-arc basins.

Perissoratis et al. [70] suggested that the main faults controlling the deformation at the offshore area eastwards of Santorini Island trend NE-SW and were activated after the previous NW-SE trending faults. The predominant fault network that formed the SantoriniAnafi valley, the Anydros Basin, and the Santorini-Amorgos Ridge (Figure 2) trends NE-SW and has resulted from the offset of the preexisting E-W faults and, secondarily, from earlier N-S faults that formed the Santorini-Anafi Ridge [61]. The E-W and N-S faults affected the older parts of the sedimentary sequence (Unit $C$ and the lower part of Unit B), while the NE-SW trending faults affected the younger parts (the uppermost part of Unit B and Unit A) of the sedimentary sequence [61]. From Kos through Amorgos to Santorini, the $65^{0}$-trending strike-slip faulting initiated around 0.6-0.8 Ma near Amorgos, 0.4 Ma east of Astypalea, and 0.2 Ma around Nisyros, while the basinal areas between Amorgos and Santorini which were formed during the deposition of Unit B prior to $0.6 \mathrm{Ma}$, now form prominent ridges [66]. The shift of the tectonic regime from E-W to NE-SW led to basin inversion [66,70]. The style of NE-SW faulting, the narrow basement ridges, and the basin inversions strongly suggest a strike-slip regime [66,71].

Sakellariou et al. [64] proposed that both Thera and Kolumbo volcanic centers occur within the NE-SW-trending Anydros graben, which constitutes a negative flower structure related to a 40-km long, possibly dextral, strike-slip zone, the Kameni-Kolumbo strike-slip, which can be extended SW-wards to the Christiana volcanic island. This is in agreement with the results of Heath et al. [72], who found that the volcanic centers of Christiana-Santorini and Kolumbo lie in a NE-SW trending basin-like structure, named as proto-Anydros Basin. They also confirm that volcanism initiated after the transition to NW-SE extension in the Pleistocene, as has been proposed also by previous models. Hübscher et al. [65], although they do not recognize strike-slip indicators within Anydros Basin, do not exclude the possibility of their existence. Nomikou et al. [62] proposed normal, NE-SW trending faulting as the main deformation mechanism. Secondary faults, showing remarkable steep dip angles, probably indicate a strike-slip component, which could explain the presence of right lateral transtensional stresses, expected by Bohnhoff et al. [48] and Sakellariou et al. [64]. Tsampouraki-Kraounaki and Sakellariou [73] suggest that the NE-SW-trending and morphologically complex area northeast of Thera until the Amorgos, Astypalea, and Kalymnos islands (which encompasses Anydhros Basin and the six subbasins of Amorgos Basin) undergoes dextral transtensional deformation accommodated by NE-SW strike-slip to oblique faults and E-W normal step-over faults. These results coincide very well with the microseismicity data of Bohnhoff et al. [48], who observed the highest seismic activity along the SW-NE striking Santorini-Amorgos zone and proposed that the Santorini-Amorgos zone is presently in the state of right-lateral transtension, acting as a major structural boundary of the volcanic arc between a seismically and volcanically quite western and an active eastern part. The results of Dimitriadis et al. [74,75] on the seismic activity of the Santorini-Kolumbo zone and of Papadimitriou et al. [76] on the caldera of Santorini are in agreement with these observations. 
On the other hand, the interpretation of the data of Nomikou et al. [54] support normal faulting as the main deformation mechanism that forms the geomorphological features of the area.

The available GPS campaigns indicate that the central Aegean acts as a coherent block moving SW with little internal deformation. Geological and geodetic data indicate that, south of the Amorgos shear zone, the sense of shear changes from the dextral transtension of the Santorini to Amorgos area and the dextral oblique rifting along the Amorgos shear zone [48,64,71,73,77], to sinistral towards the southeast. Tzanis et al. [78] studied the kinematic regime of the Santorini area by using gravity, magnetotelluric, and DGPS data. According to their interpretation, kinematics in that area is characterized by NW-SE dextral strike slip faults and NE-SW normal to sinistral faults generated by N-S oriented $\sigma 1$ and E-W oriented $\sigma 3$. Very recently, Briole et al. [41], based on a dense network of GPS stations, analyzed the velocities of the period 2000-2020, and they quantified several characteristics of the deformation of the Aegean. They built a kinematic model comprising ten crustal blocks corresponding to areas where the velocities present homogeneous gradients. The major fault zones and zones of localized deformation constitute boundaries between the blocks. Amorgos basin fault zone is one of these boundaries where the authors recognize a dextral transtensional movement of $4.5 \mathrm{~mm}$ year-1 between the Amorgos and Astypalea islands.

\subsection{The 1956 Amorgos Earthquake}

The exceptional magnitude 7.8 of the 9 July 1956, Amorgos earthquake, and the tsunami that followed, have affected that area and caused several damages on the neighboring islands. A second seismic event, with a magnitude of $M=7.2$, followed the first earthquake $13 \mathrm{~min}$ later in the same region. The focal mechanism of the Amorgos 1956 earthquake and the precise location of its epicenter are still debated. Papadopoulos and Pavlides [59] noted that the 1956 mainshock, the epicenter of its largest aftershock, and the volcanic centers of Santorini, Christiana, and Columbo strike along the same structural line, indicating a possible geodynamic association between the seismotectonic and volcanotectonic processes in this part of the South Aegean. Various studies have been conducted in order to understand the focal mechanism of the Amorgos earthquake. The proposed focal mechanisms vary between dextral strike-slip and dip-slip movement on a NE-SW-trending SE dipping fault [79] (and references therein). Okal et al. [79] and Shirokova [80] proposed a normal faulting geometry, while Papazachos and Delibassis [81] and Ritsema [82] suggested strike-slip as the focal mechanism. Brüstle et al. [83] proposed a dextral SE dipping normal fault plane solution as the focal mechanism for the first event and a thrust fault mechanism for the second.

\section{Materials and Methods}

This study uses two data sets, swath bathymetry and seismic profiles, collected during various cruises of HCMR's research vessel AEGAEO. Swath bathymetry data were collected with the use of a hull-mounted multibeam system ELAG SEABEAM $2120(20 \mathrm{kHz})$ and $1180(180 \mathrm{kHz})$ as follows (Figure 3): (i) around Santorini Island in 2001 [84] and 2006 (THERA project [85]); (ii) east and southeast of Astypalea in 2007-2008 [86]; (iii) between Amorgos, Anafi, and Astypalea Islands in 2016 during the Eurofleets2 LGT-AMORGOS-56 cruise; (iv) east of Amorgos Island and south of Anaphi and Astypalea Islands in 2017 (SOUTH AEGEAN cruise). All recent and older swath bathymetry data were integrated into one data set, processed using the MB-System, PDS 2000, and Global Mapper software and reprocessed at $20 \mathrm{~m}$ resolution in Arc-GIS. 

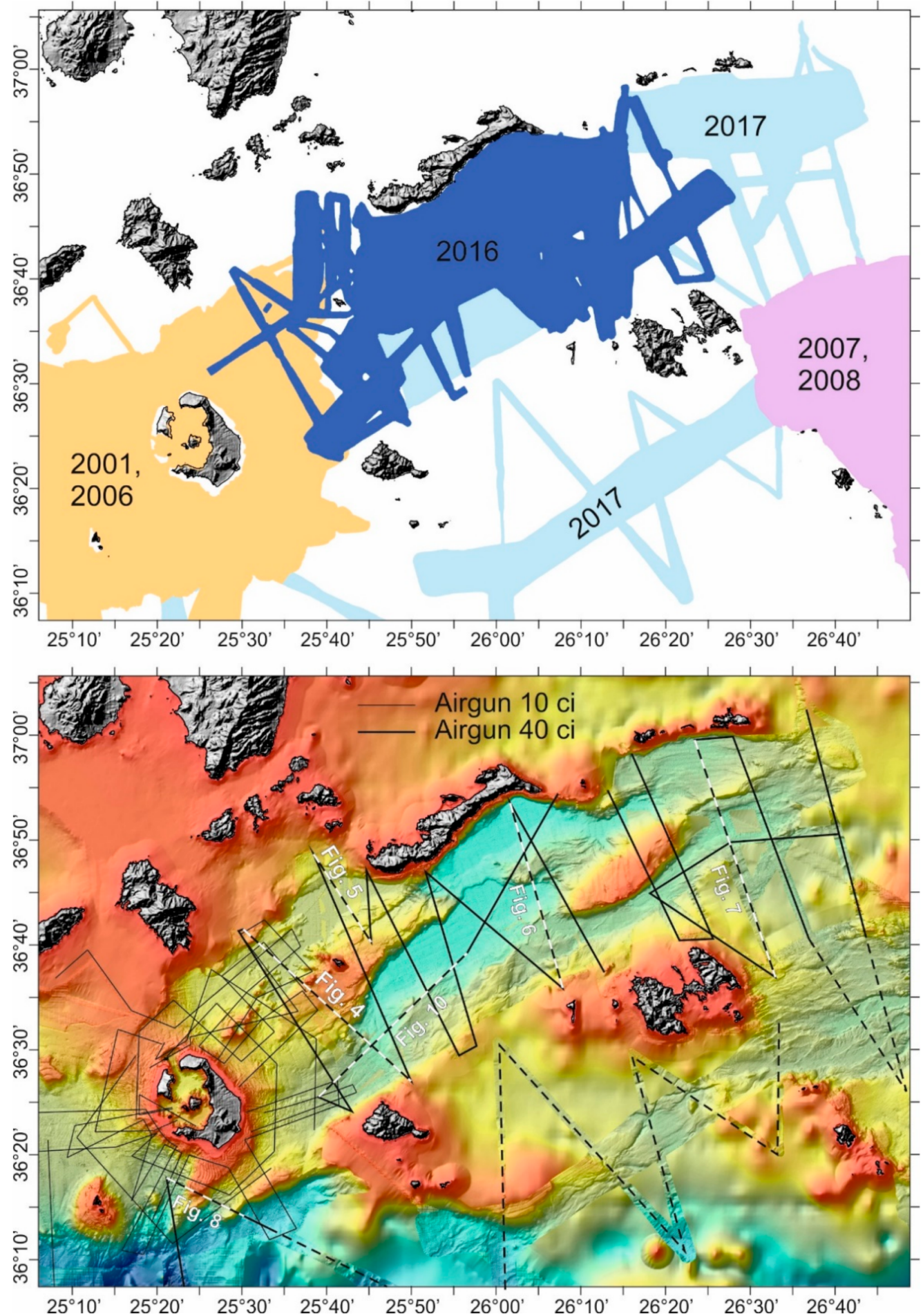

Figure 3. Left: Swath bathymetry coverage and year of acquisition. Right: Swath bathymetry map of the study area showing the location of the airgun $10 \mathrm{ci}$ and $40 \mathrm{ci}$ seismic lines acquired in the study area. Dashed white and black lines show the seismic lines described in the text.

Single channel seismic profiles were collected during the following three cruises (Figure 3): airgun $10 \mathrm{in}^{3}$ profiles in 2006 around Santorini (THERA project) and airgun $40 \mathrm{in}^{3}$ in 2016 (Eurofleets2 LGT-AMORGOS-56 cruise) and in 2017 (SOUTH AEGEAN cruise). In all surveys, the sound source was towed at 2-5-3 $\mathrm{m}$ water depth behind the stern of the vessel. The 2006 profiles have been recorded on a surface towed SIG seismic streamer (65 m active length, 48 hydrophones at $1 \mathrm{~m}$ spacing) Triton Imaging, Inc. acquisition 
software and hardware at 2 s shooting rate. The 2016 and 2017 profiles have been recorded on CodaOctopus DA4G 2000 acquisition software and hardware at 3 s shooting rate. The CodaOctapus Survey Engine software has been used for the processing of all profiles and the improvement of the signal-to-noise ratio when needed. Processing included adjustment of time varied gain (TVG), signal rectification (when necessary), across track smoothing, and pass-band frequency filtering between $100 \mathrm{~Hz}$ and $300 \mathrm{~Hz}$.

\section{Results}

\subsection{Bathymetry-Geomorphology}

The Santorini Amorgos Shear Zone is a composite morphological feature that includes seven NE-SW trending, spindle-shaped or elongated basins and two uplifted, shallow ridges. The names of the basins, from the northwest to the southeast, are: Anydros (AdB), Anafi (AnB), Amorgos South (ASB), Amorgos North (ANB), Kinairos (KB), Astypalea North (AsNB), and Astypalea South Basins (AsSB). The ridges are named as Astypalea (AsR) and Anydros (AdR) Ridges, while both display two splays (Figure 2). Two more, smaller ridges, Akrotiri (AkR) and Anafi (AnR), occur in the southwestern part of the study area. Their main morphological characteristics are presented in Table 1.

Table 1. Morphological characteristics of SASZ basins and ridges.

\begin{tabular}{|c|c|c|c|c|c|}
\hline Geomorphological Feature & $\begin{array}{l}\text { Length } \\
(\mathrm{km})\end{array}$ & $\begin{array}{l}\text { Width } \\
(\mathrm{km})\end{array}$ & Orientation & Margins/Slopes & Other Information \\
\hline Astypalea Ridge (AsR) & 29 & 9 & NE-SW & $\begin{array}{l}\text { Steep faulted SE-dipping } \\
\text { slope }\end{array}$ & $\begin{array}{l}\text { Two branches (AsRa, } \\
\text { AsRb) }\end{array}$ \\
\hline Anydros Ridge (AdR) & 37 & 11 & NE-SW & $\begin{array}{l}\text { Steep faulted SE-dipping } \\
\text { slopes }\end{array}$ & $\begin{array}{l}\text { Two branches (AdRa, } \\
\text { AdRb) }\end{array}$ \\
\hline Akrotiri Ridge (AkR) & 17 & $<5$ & NE-SW & Steep NW and SE slopes & SW of Santorini Island \\
\hline Anafi Ridge (AnR) & 30 & $<6$ & NE-SW & Steep NW and SE slopes & Ends on Anafi Island \\
\hline Anydros Basin (AdB) & $>42$ & $<10$ & NE-SW & $\begin{array}{l}\text { Steep faulted NE margin, } \\
\text { variably } \\
\text { steep NW and SE margins }\end{array}$ & $\begin{array}{l}\text { It hosts the Kolumbo } \\
\text { volcanic chain. } \\
\text { N-ward asymmetry } \\
\text { of the NE part of the basin }\end{array}$ \\
\hline Anafi Basin (AnB) & 40 & $<8$ & NE-SW & $\begin{array}{l}\text { Variably steep SE } \\
\text { and NW margins }\end{array}$ & S-ward asymmetry \\
\hline Amorgos South Basin (ASB) & 43 & 11 & NE-SW & $\begin{array}{l}\text { Steep faulted NW margin. } \\
\text { Gently sloping } S \\
\text { and SE margins. }\end{array}$ & $\mathrm{N}$-ward asymmetry \\
\hline Amorgos North Basin (ANB) & 34 & 9 & NE-SW & $\begin{array}{l}\text { Steep faulted NW margin. } \\
\text { Gently sloping S } \\
\text { and SE margins. }\end{array}$ & $\mathrm{N}$-ward asymmetry \\
\hline Kinairos Basin (KB) & 32 & 11 & ENE-WSW & $\begin{array}{l}\text { Steep northern } \\
\text { margins }\end{array}$ & $\mathrm{N}$-ward asymmetry \\
\hline Astypalea North Basin (AsNB) & 63 & 6 & NE-SW & $\begin{array}{l}\text { Steep, faulted } \\
\text { northern margin }\end{array}$ & $\mathrm{N}$-ward asymmetry \\
\hline Astypalea South Basin (AsSb) & 22 & 18 & ENE-WSW & & \\
\hline
\end{tabular}

Astypalea Ridge (AsR) is located on the NE part of the study area and separates Kinairos and Amorgos North basins from Astypalea North Basin. Its main body is located southeast of Amorgos Island and displays elongated, flat-topped shape. The ridge is extended approximately $19 \mathrm{~km}$ to the NE as a very narrow elevation of the seafloor which separates Kinairos Basin from the eastern part of Astypalea North Basin. To the SW, it is divided into two branches. The W-E trending northern branch (AsRa) splays out of the northwestern side of the main body and separates Amorgos North from Amorgos 
South basins. A series of SW dipping faulted escarpments separate it from the main body. Its prolongation towards the west is connected with the Anydros Ridge. The southern branch (AsRb) initiates in the southwestern tip of AsR and prolongs towards the SW. It separates the Amorgos South from the Astypalea North basin and merges with the steep slope NE of Anafi Island.

The NE-SW trending, elongated Anydros Ridge (AdR) is located at the western part of the study area. Its summit at the center of the ridge forms the Anydros islet. Towards the SW, the top of the ridge deepens gradually and smoothly, to form a roughly $400 \mathrm{~m}$ deep morphological saddle between Anydros Ridge and the steep eastern slopes of Santorini. Taking into consideration the main morphological direction prevailing in the study area, the Anydros Ridge is in line with the mountainous part (Profitis Elias Mt.) of southern Santorini and with the Akrotiri Ridge. The northeastern part is divided into two branches by the prolongation of the Amorgos escarpment. The northern branch (AdRa) connects with the steep, NE-SW trending slope off Amorgos, while the southern branch (AdRb) connects with AsRa.

Akrotiri Ridge (AkR) constitutes the underwater prolongation of the southern part of Santorini towards the SW. AkR extends roughly $20 \mathrm{~km}$ off the southwestern coast of Santorini and its top displays rugged morphology. It separates Christiana Basin to the NW [77] from the westernmost part of Anafi Basin to the SE.

Anafi Ridge (AnR) runs parallel to and south of Akrotiri Ridge. The island of Anafi marks the northeastern termination of the AnR. It separates the $400 \mathrm{~m}$ western part of Anafi Basin from the over $1000 \mathrm{~m}$ deep Cretan Basin to the south.

The narrow, elongated Anydros Basin is located NE of Santorini. It is bounded to the NW by the faulted slopes of the islands of Ios and Koufonisia and to the SE by Anydros Ridge. The floor of the SE part of the basin hosts more than 20 volcanic cones, including the submarine volcano Kolumbo [87]. The cones display conical or sub-conical shape, and their NE-SW linear distribution follows the direction of the long basin axis. Contrary to the SW part, the seafloor on the NE part of the basin is flat and free of volcanic structures.

Amorgos North (ANB) and Amorgos South (ASB) basins display similar morphological characteristics. Both basins display morphological asymmetry, with steep, faulted, northern margins. ASB is a spindle shaped basin, bounded to the North by the Anydros Ridge and the northern branch of Astypalea Ridge (AsRa). The southern boundary is formed by the NE-SW trending slope of Anafi and the southern branch of Astypalea Ridge (AsRb). ANB is a triangular to lazy-S-shaped basin. The steep slopes of Amorgos Island form the northern margin of ANB, while the northern branch of Astypalea Ridge constitutes the southern margin.

Kinairos Basin has been developed south of the islands of Kinairos and Levitha. It displays northward asymmetry with a steep northern boundary and a smooth southern margin to the northeastern prolongation of Astypalea Ridge.

A gentle elevation of the seafloor divides Astypalea Basin into two sub-basins. The northern one (AsNB) is characterized by a very narrow and elongated shape, which shows a convex shape, following the curvature of Astypalea Ridge. The southern one (AsSB), east of Astypalea Island, displays more irregular and asymmetric shape. However, a thorough analysis and description of AsSB does not fall within the goals of the present work.

Anafi Basin is bounded to the north by Akrotiri Ridge, Santorini Island, and Anydros Ridge and to the South by Anafi Ridge, Anafi Island, and the shallow plateau between Anafi and Astypalea. Anafi Basin displays elongated shape in NE-SW direction and, opposite to the previously described basins, is characterized by southward asymmetry.

\subsection{Seismic Stratigraphy: Basins}

Seven basins (AdB, AnB, ASB, ANB, KB, AsSB, AsNB) separated by structurally uplifted ridges have been identified in the study area. Similarities and differences, observed in the seismic stratigraphy of the basins, provide insights into the Plio-Quaternary evolution of the Santorini-Amorgos Shear Zone. Despite some variations and differences in the 
seismic stratigraphy of each basin, a common designation was used to describe the seismic packages constituting their sedimentary infill. Six successive seismic units have been mapped within the sedimentary infill of the basins, named from top to bottom as Units 1 , $2,3,4,5$, and 6 .

Unit 1 , the youngest one, is characterized by well stratified, closely spaced, high amplitude, coherent and continuous reflectors running parallel to the seafloor. Unit 2 displays a more complex seismic character and shows differences from basin to basin, which will be discussed in more detail in the analysis of the seismic stratigraphy of each basin. It is mostly characterized by high amplitude, semi-continuous, undulating, and medium coherent reflectors, alternating with low coherent energy and internal high amplitude, discontinuous and irregular reflectors. Unit 3 is defined by a rhythmic alternation of high amplitude, continuous and parallel reflections with transparent and semi-continuous reflections and/or incoherent, low amplitude discontinuous reflectors. Unit 4 is characterized mainly by high amplitude, continuous, parallel reflectors which, in some cases, become more undulating and discontinuous with depth. Unit 5 shows a rhythmic alternation of high amplitude, continuous and parallel reflectors with semi-continuous, medium amplitude and wavy reflectors Finally, Unit 6 is characterized by an upper surface with high to medium amplitude, undulating, incoherent, and transparent reflectors, while, at the base of Unit 6, in some areas, a highly irregular, rugged reflector, which marks the transition from Unit 6 to the acoustic basement, has been observed.

The interpretation of the seismic stratigraphy revealed at least 4 major unconformities in nearly all basins suggesting that successive, major tectonic events have affected the entire area of Santorini-Amorgos Shear Zone (SASZ) during its evolution. They are named from top to bottom as U1, U2, U3, and U4. U1 is defined by a high amplitude and continuous reflector, and it is a relatively shallow unconformity, at roughly 30-50 msec depth below the seafloor that separates seismic Unit 1 above from seismic Unit 2 below. It has been mapped in the Amorgos South and Amorgos North basins, within the Astypalea North and South basins, in Anafi Basin, and in the western part of Anydros Basin (Figure 4, Figure 5, Figure 6, Figure 7 and Figure 10).

Unconformity U2 is imaged as a high amplitude, erosional, undulating reflector that separates Unit 2 from Unit 3. It has been mapped in the Anydros, Anafi, Kinairos, Amorgos South, and Amorgos North basins and in the southwestern part of Amorgos South Basin (Figure 4, Figure 5, Figure 6, Figure 7 and Figure 10). The internal reflectors of Unit 3 are truncated upwards by the Unconformity U2.

Unconformity U3 truncates the reflectors of the underlying Unit 4, while the reflectors of the overlying Unit 3 display onlap relationship. It has been mapped on the seismic profiles of all basins (Figure 4, Figure 5, Figure 6, Figure 7 and Figure 10) and marks a major change in the evolution of the entire area. All units $(4,5,6)$ below U3 display a roughly constant thickness across the basins; they are tilted northwards, uplifted towards the south and occur on the uplifted ridges that separate the basins. The units above U3 (3, $2,1)$ are deposited only within the basins and their thickness increases drastically towards the northern margins of the basins. Thus, Unconformity U3 marks the onset of enhanced tectonic activity along the present, major, basin-bounding faults that led to significant northward tilting of the lower parts of the sedimentary infill of the basins, enhanced subsidence close to northern margins of the basins, uplift and formation of the ridges along the southern margins. The tilting and uplifting of the basin's sediments has begun after the deposition of Unit 4 and has evolved simultaneously with the deposition of the sediments of Units 3, 2, and 1 .

Unconformity U4 is a high amplitude and continuous reflector, which is mainly recognizable within the Amorgos North and Amorgos South basins, in the eastern part of Anydros Basin, in Anafi Basin and Kinairos Basin (Figure 4, Figure 5, Figure 6, Figure 7 and Figure 10) and separates Unit 4 from Unit 5 below.

Table 2 presents the results obtained from the comparison of the analysis of the seismic stratigraphy of the current study with the results of previous studies. 


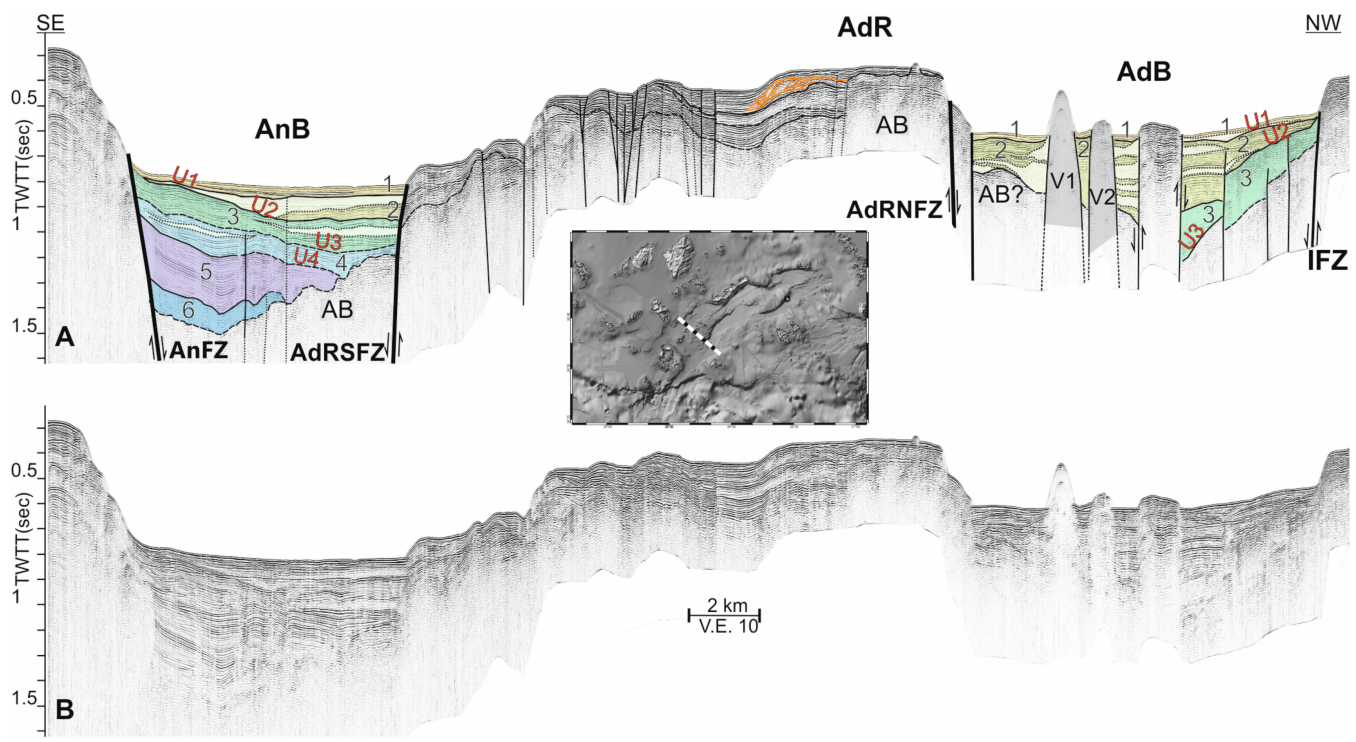

Figure 4. Air gun 40 ci seismic profile crossing the western part of Anydros Basin (AdB), Anydros Ridge (AdR), and Anafi Basin (AnB). The numbers 1 to 6 represent the six seismic units described in the text. U1, U2, U3, and U4 correspond to the observed, major unconformities. AB: Acoustic Basement, AdRNFZ: Anydros Ridge North Fault Zone, AdRSFZ: Anydros Ridge South Fault Zone, AnFZ: Anafi Fault Zone IFZ: Ios Fault Zone. V1 and V2: Submarine volcanic domes of Kolumbo chain.

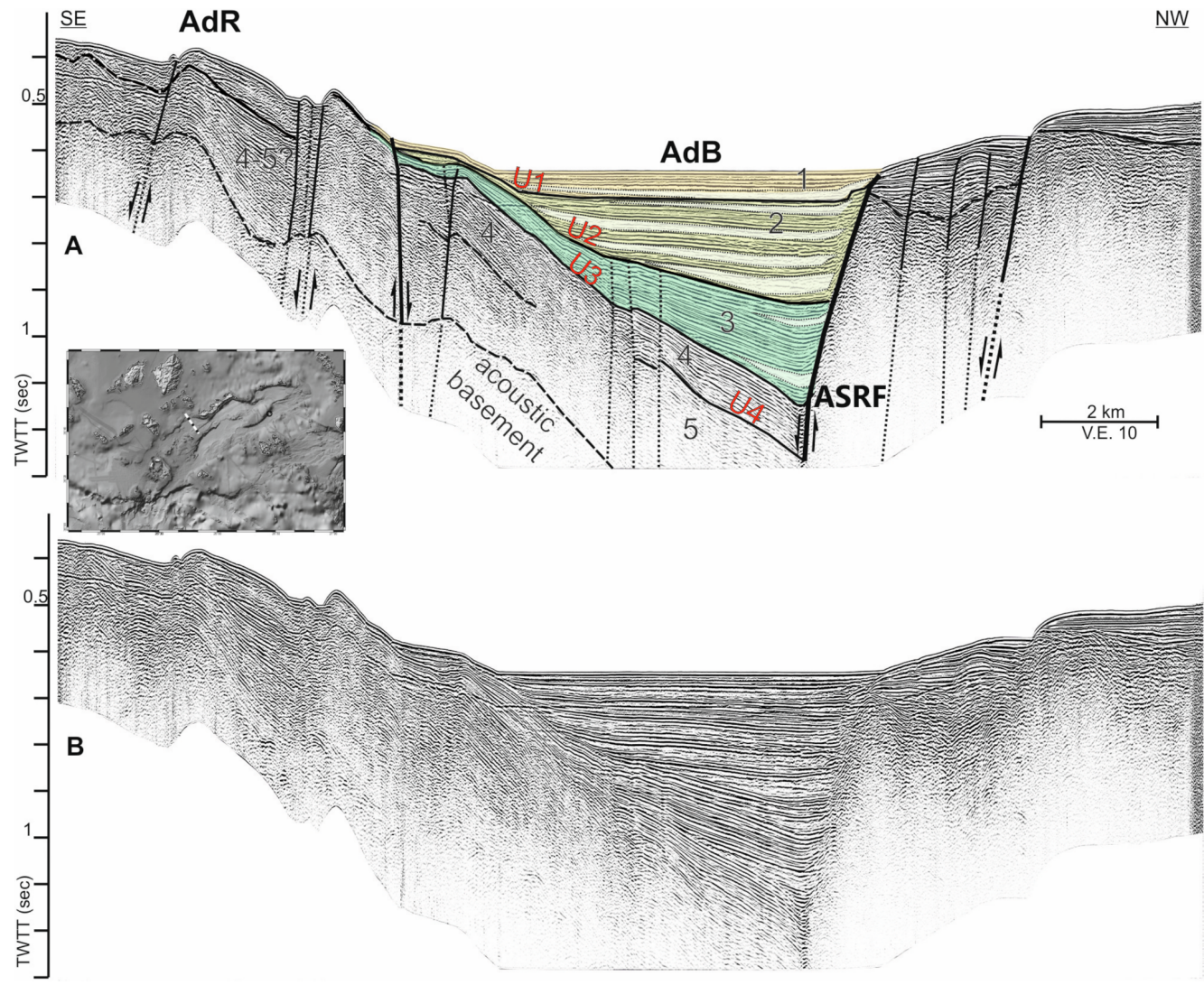

Figure 5. Airgun 40 ci seismic profile across the eastern part of Anydros Basin (AdB). AdR: Anydros Ridge, ASRF: Amorgos South Relay Fault. Terminology and symbols as in Figure 4. 


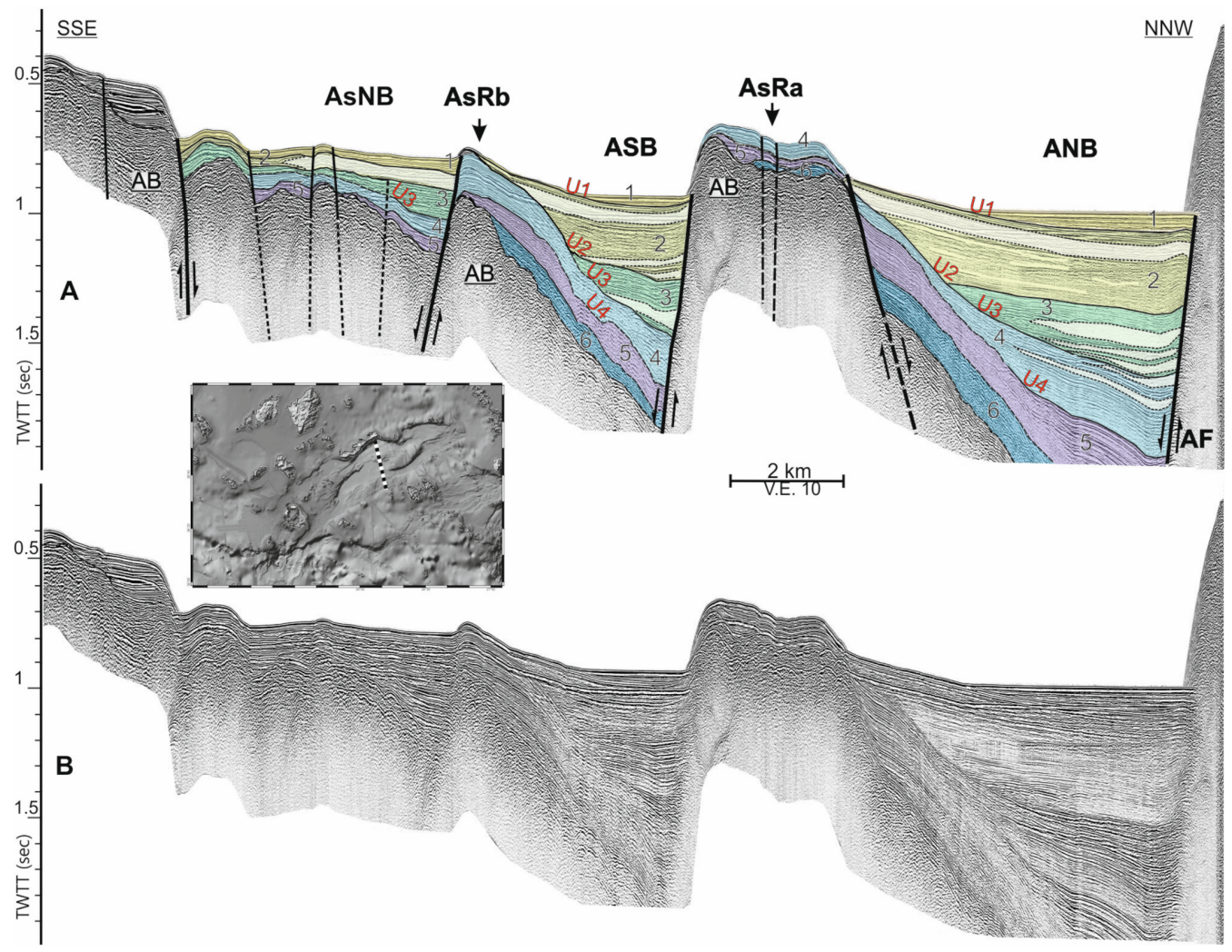

Figure 6. Airgun 40 ci seismic profile across the central part of Amorgos North Basin (ANB), the eastern part of Amorgos South Basin (ASB) and the western part of Astypalea North Basin (AsNB). Terminology and symbols as in Figure 4. AF: Amorgos Fault, AsRa: north splay of Astypalea Ridge and AsRb: south splay of Astypalea Ridge.

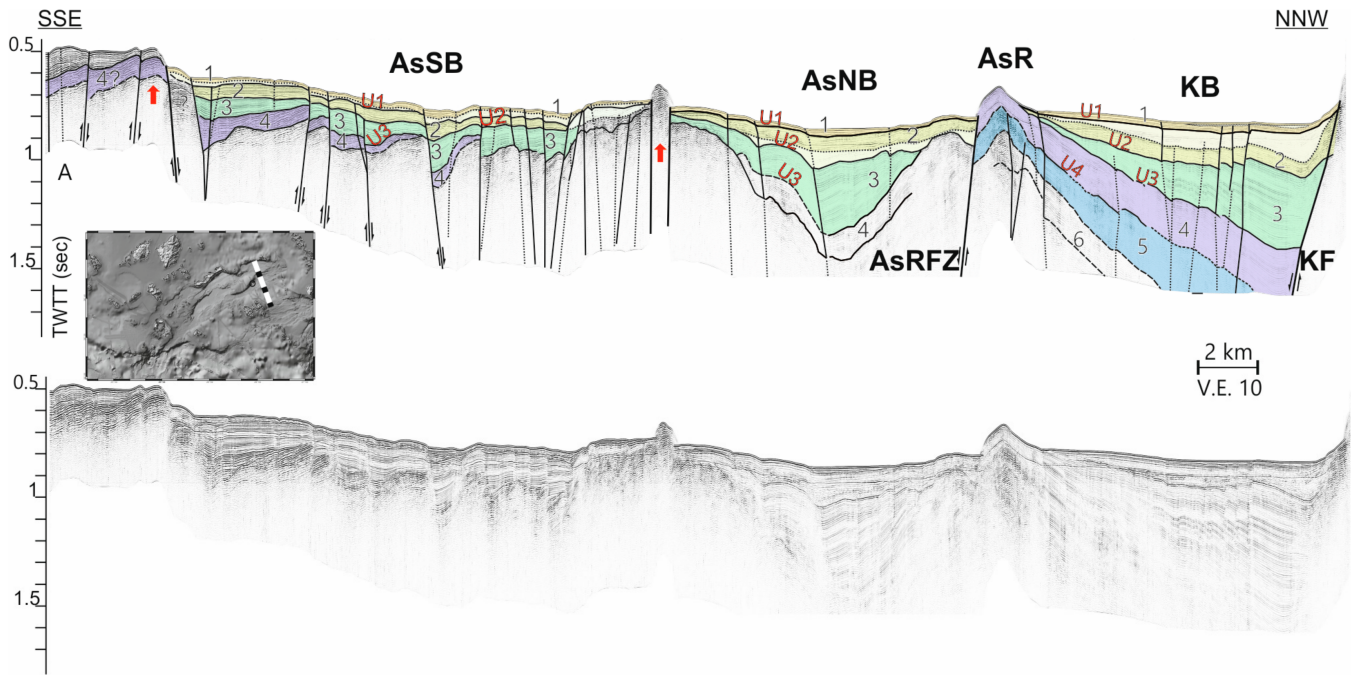

Figure 7. Airgun 40 ci seismic profile crossing the central part of Kinairos Basin (KB), the eastern part of Astypalea North Basin (AsNB), and Astypalea South Basin (AsSB). Terminology and symbols as in Figure 4. AsRF: Astypalea Ridge Fault, KF: Kinairos Fault. 
Table 2. Seismic stratigraphic features in the current study and in the literature.

\begin{tabular}{|c|c|c|c|}
\hline Current Study & Piper and Perissoratis [66] & Nomikou et al. [62] & Nomikou et al. [54] \\
\hline Unit 1 & A1 & AB-6 & Amb6, Sab6, Ab6 \\
\hline Unconformity U1 & UR3 (150-190 ka years) & $a b-5$ & \\
\hline Unit 2 & A2 & AB-5 & Amb5, Sab5, Ab5 \\
\hline Unconformity U2 & $\begin{array}{c}\text { UR2 and/or UA1 } \\
\text { (Plio/Quaternary boundary) }\end{array}$ & & \\
\hline Unit 3 & B & $\mathrm{AB}-4$ and/or $\mathrm{AB}-3, \mathrm{AB}-2$ & $\begin{array}{l}\text { Upper part of Amb4, Sab4, } \\
\qquad \mathrm{Ab} 4\end{array}$ \\
\hline Unconformity U3 & $\begin{array}{c}\text { UR2 and/or UA1 } \\
\text { (Plio/Quaternary boundary) }\end{array}$ & & \\
\hline \multicolumn{4}{|l|}{ Unit 4} \\
\hline \multicolumn{4}{|l|}{ Unconformity U4 } \\
\hline Unit 5 & & AB-2 (?) & Sab3, Ab3 \\
\hline Unit 6 & & AB-1 (?) & $\mathrm{Sab} 2, \mathrm{Ab} 2$ \\
\hline
\end{tabular}

\subsubsection{Anafi Basin (AnB)}

The seismic stratigraphy of AnB is very well illustrated in Figure 4. Sediments of about 700 msec thickness lie uncomfortably on the acoustic basement (AB) between the SW and NE faulted margins (Anafi and Anydros Ridge faults, respectively). The acoustic basement exhibits a high amplitude, undulating, discontinuous surface, which is not well distinguishable throughout the entire basin, with high amplitude, discontinuous internal reflectors. Units from 1 to 6 have been recognized within the sedimentary sequence.

Unit 1 shows a slight variation in the thickness along the south and north margins of the basin, of the order of magnitude of $20 \mathrm{msec}$. Unconformity U1, separates Unit 1 above from Unit 2 below. The upper part of Unit 2 is characterized by a chaotic layer of discontinuous, transparent, undulating, and high amplitude reflectors. The chaotic seismic reflections are interpreted as mass transport deposits, which are probably related to slope instability and gravitational sliding of material from the southern steep slopes of Anydros Ridge. The reflectors of Unit 2 onlap unconformity U2, that separates Unit 2 above from Unit 3 below. The latter shows a mean thickness of about 100 msec across the basin, lies horizontally in the northern part of the basin and climbs up towards the southern margin. At least one layer with chaotic, undulating, and high amplitude reflectors has been mapped within Unit 3 and has been interpreted as a mass transport deposit, possibly related to enhanced tectonic activity along the northwestern margin of the basin. Despite the fact that the reflectors of this unit lie conformably on the following unit (Figure 4), unconformity U3 separates those two units, as stated below in the description of the seismic stratigraphy of the other basins. Unit 4 underlies Unit 3 and shows a maximum thickness of $100 \mathrm{msec}$ at the center of the basin. Its internal reflectors display a divergent character close to the southeastern margin. The southeastern part of Unit 4, close to the SE faulted margin, lies unconformably on the eroded acoustic basement (AB).

Unit 5 shows a maximum thickness of about 250 msec close to the southeastern margin, indicating rapid subsidence of the basin during the deposition of this unit. Unconformity U4 that separates Unit 4 from Unit 5 can be traced only at the northwestern part of the basin. The chaotic character of Unit 5, which rests unconformably in the NW part, does not allow the separation of the top of Unit 5 from the base of Unit 4. On the central and the SE part of Anafi Basin (Figure 4), Unit 5 follows the inclination and the geometry of Unit 4 and is characterized by very well illustrated, high amplitude, continuous, closely spaced, and parallel reflectors.

Unit 6 can be mapped at a mean depth of 1400 msec. Due to the depth in which it is located and its acoustic seismic character, the interface between it and the presumable 
acoustic basement is not well discernible. Nevertheless, the undulating, discontinuous base of Unit 6 indicates that this seismic unit lies unconformably on the eroded basement.

\subsubsection{Anydros Basin (AdB)}

Anydros Basin is separated from Anafi Basin by the Anydros Ridge (Figures 2 and 4). The structure and seismic stratigraphy of the northeastern and southwestern parts of AdB are remarkably different (Figures 4 and 5). A well stratified sedimentary sequence with evident northward asymmetry characterizes the NE part of AdB (Figure 5). On the contrary, the sedimentary infill in the SW part of AdB indicates uniform subsidence and is intruded by multiple volcanic bodies that create cones and domes on the seafloor (Figure 4). The subsidence of AdB has evolved between the Ios (IF) and Akrotiri-Anydros (AdF) faultzones. Interestingly, the volcanic activity in the Santorini-Amorgos area, which includes the volcanic complex of Santorini (Thera) and the Kolumbo volcanic chain, occurs exclusively within Anydros Basin, while the volcanic domes of Christiana Islets occur on the southwestern prolongation of AdB.

Only the three upper units (Units 1 to 3 ) have been recognized within the sedimentary infill in the SW part of AdB. Unit 1 ( 20 msec thickness) rests unconformably on Unit 2 (Unconformity U1). The latter shows a maximum thickness of around $280 \mathrm{msec}$. Semichaotic facies of little coherent energy showing locally high amplitude, discontinuous reflectors within this unit suggests that they are mass transport deposits derived from the margins of the basin, or they are volcano-clastic deposits (pyroclastic flows, perhaps), originating from any of the adjacent volcanic centers. Figure 4 shows that Unit 2 thins out towards the northern faulted margin, while, towards the southern one, its thickness remains constant, at roughly $100 \mathrm{msec}$. A high amplitude, thick, and morphologically irregular reflector marks the erosional interface between Unit 2 and the underlying acoustic basement $(\mathrm{AB})$, in the southern part of Anydros Basin (Figure 4). In the northwestern part of $A d B$, unconformity U2 separates Unit 2 (above) from Unit 3 (below). Unit 3 shows internal changes in amplitude characteristics and the reflectors close to the northern margin show a divergent character. Unit 3 lies unconformably (Unconformity U3) on the underlying layer.

The flat seafloor and the horizontal stratigraphic layering of the SW part of AdB, shown on the seismic profile of Figure 4, are interrupted by three vertical, elevated features. The two southernmost ones (V1 and V2) display a strongly reflective seafloor, internal chaotic seismic character, steep slopes, and sharp contacts with the surrounding sedimentary deposits. They coincide with two of the submarine volcanic domes of the Kolumbo chain, already mapped earlier $[62,87]$. The third uplifted structure, north of the previous ones, has also been described by Nomikou et al. [62]. This structure displays flattened, strongly reflective top and internal layered seismic character, characterized by high amplitude, undulating, and semi-continuous reflectors. It is bounded towards NW and SE and uplifted by two, steep, opposite facing, high angle faults $\left(\sim 85^{\circ}\right.$ the northern one and $\sim 70^{\circ}$ the southern), pointing to a pop-up like, compressional structure developed between two strike-slip faults. The downward flexure of the surrounding, subsiding sedimentary layers, close to both faults, supports the previous interpretation.

As mentioned above the NE part of AdB displays significant variations in the geometry and the seismic stratigraphy in respect to the SW part (Figure 5). A very well stratified sedimentary sequence with maximum thickness exceeding $600 \mathrm{msec}$ characterizes the NE part of AdB. Units 1 to 5 have been mapped within its sedimentary infill. Unit 1 shows a mean thickness of $50 \mathrm{msec}$, while Unit 2 shows a maximum thickness of $230 \mathrm{msec}$ close to the northern margin. At least five chaotic layers, with low coherent energy and internal high amplitude, discontinuous and irregular reflectors have been recognized within Unit 2. The highly disrupted seismic character, the recognizable toe region at the upper and lower part (Figure 5), and their proximity to the unstable faulted northern margin leads to the conclusion that they are MTDs related to slope failures [88].

Unconformity U2 separates Unit 2 from Unit 3 . The latter shows a maximum thickness of about 200 msec close to the northern margin (Amorgos South Relay Fault), which, 
similarly to Unit 2, thins out towards the southern margin. At least two, relatively small and thin MTDs have been mapped within this Unit close to the northern margin. This Unit lies unconformably on Unit 4 towards the northern margin (Unconformity U3). Unlike Units 2 and 3, Unit 4 displays a constant thickness of roughly $110 \mathrm{msec}$ across the basin, indicating thus uniform subsidence during its deposition. Its geometry follows the one of its interface with the overlying Unit 3. The base of Unit 4 occurs at $1230 \mathrm{msec}$ depth close to the northern margin. It ascents continuously towards the southern margin, the Anydros Ridge, and reaches minimum depth of roughly $500 \mathrm{msec}$ or less below the top of the Ridge. Its seismic character becomes more undulating and discontinuous with depth. The lowermost recognizable unit is Unit 5, the reflections of which follow the geometry of Unit 4 and are tilted upwards on Anydros Ridge.

Húbscer et al. [65] and Nomikou et al. [62] recognize moat channels and mounded contourites on the NW part of the basin, in the lower part of the basin's infill. Their stratigraphic position corresponds to the lower half of unit 3 and the underling units, as defined in the current study.

\subsubsection{Amorgos North (ANB) and Amorgos South (ASB) Basins}

Amorgos North (ANB) and Amorgos South (ASB) Basins are described here in parallel because, as shown hereafter, they display remarkable seismic stratigraphic and structural similarities and can be considered as twin basins. They are separated from each other by the Northern Splay of Astypalea Ridge (AsRa), from the Anydros Basin to the North by the Anydros Ridge and from Astypalea Basin to the South by the Astypalea Ridge (AsR) and its Southern Splay (AsRb). The similitudes between the two basins are obvious on the seismic profile of Figure 6. The latter crosscuts the central, widest part of ANB (roughly $10 \mathrm{~km}$ width) and the eastern part of ASB with $5.5 \mathrm{~km}$ width.

Six different seismic units (Units from 1 to 6), that are significantly tilted towards the north, can be identified within the Amorgos North and Amorgos South basins, while the development of both basins is mainly controlled by the northern marginal faults. The sedimentary sequence lies on top of the acoustic basement, which shows a rugged surface topography. An elevation of the acoustic basement separates those basins and forms the North Splay of Astypalea Ridge (AsRa). Unit 1 lies on the seafloor and gradually thickens towards the north. The maximum thickness shown in the ANB is about $50-60 \mathrm{msec}$, and, in ASB, it is approximately 80-90 msec. Unit 1 onlaps unconformity U1, which separates it from the underlying Unit 2. The latter shows a maximum thickness exceeding $300 \mathrm{msec}$ in the ASB and close to $300 \mathrm{msec}$ in the ANB. Around 20-30 msec below the top of Unit 2, a chaotic layer with internal high amplitude, discontinuous and irregular reflectors, has been mapped in both basins, the thickness of which remains constant through the basins axis and is approximately $50 \mathrm{msec}$. This layer has been interpreted as MTD and is probably related to a rapid subsidence of the northern parts of the basins. In ASB, similar layers of smaller thickness have been mapped within the lowermost part of Unit 2.

Unconformity U2 separates Unit 2 above, from Unit 3 below, while, on the southern part of the basins, the reflectors of Unit 2 onlap unconformably (unconformity U3) on Unit 4. Unit 3 shows a maximum thickness of $170 \mathrm{msec}$ in ASB and of $260 \mathrm{msec}$ in ANB. Internal, chaotic layers at the lowermost part of Unit 3 have been interpreted as MTDs, associated with slope instabilities along the margins. Unit 4 lies below Unit 3 and close to the northern faulted margins of ASB and ANB shows its maximum thickness of 200 and $300 \mathrm{msec}$, respectively. Towards the southern margins, it thins and pinches out on the uplifted acoustic basement, which forms the north and south splays of Astypalea Ridge (AsRa and AsRb). As aforementioned, the internal reflectors of Unit 2 and Unit 3 onlap the top of Unit 4 towards the south, while the reflectors of the latter are truncated by the angular unconformity U3.

Unconformity U4 separates Unit 4 from Unit 5. The distinction of Unit 5 from the Unit 6 is not easy, and the interface that separates them cannot be mapped in detail. However, following the geometry and morphology of the adjacent layers, the dashed line 
in Figure 6 attempts to define this surface. A highly irregular, rugged reflector marks the transition from Unit 6 to the acoustic basement. High amplitude and non-stratified internal reflectors occur on the upper part, while the lower part is acoustically transparent. It is worth noting that, like in the NE part of Anydros Basin, the lowermost parts of the sedimentary sequence in Amorgos North and in Amorgos South basins have been tilted and uplifted upwards, covering the north and south splays of Astypalea Ridge.

\subsubsection{Astypalea North Basin (AsNB)}

A SW-NE trending structural uplift of the acoustic basement and its sedimentary cover, which consists of Units 4, 5, and 6, forms the south splay of Astypalea Ridge and separates the Amorgos South Basin (ASB) from Astypalea North Basin (AsNB) (Figure 6). An elongated uplift of the acoustic basement separates Astypalea Basin into two sub-basins: a northern one (AsNB) and a southern one (AsSB). At least 4 seismic units have been mapped in the upper parts of the sedimentary sequences of the two sub-basins (Figure 7). The lower parts of the basins' infill have not been imaged properly due to rapid signal attenuation with depth. The westernmost part of AsNB displays northward asymmetry, similar to the previously described basins. Seismic units 1-5 have been mapped within AsNB. They show smaller thickness compared to the other basins which was to be expected, since the sedimentary infill of Astypalea Basin is slightly smaller. Seismic units 4 and 5 of ASB that have been uplifted on Astypalea Ridge, have also been mapped at the base of the sedimentary sequence of AsNB (Figure 6). Unit 5 has been deposited on the acoustic basement of AsNB. Therefore, Unit 6 observed in ASB, may not have been deposited in Astypalea Basin. Unit 1 is of constant thickness, while Units 2, 3, 4, and 5 show maximum thickness close to the northern faulted margin. At the base of Unit 3, an undulating surface that truncates the underlying Unit 4 is related to unconformity U3.

The easternmost part of AsNB displays a more symmetric shape. Two faulted margins northwards (AsRF) and southwards define the basin. The seismic profile of Figure 7 shows a well stratified sedimentary infill in AsNB, whose thickness exceeds $600 \mathrm{msec}$ at the center of the basin and thins out towards the margins. The lowermost part of the sedimentary sequence is not very well recorded, so only the upper seismic units (1 to 4 ) have been recognized.

\subsubsection{Astypalea South Basin (AsSB)}

Astypalea South Basin (AsSB) displays a more circular shape compared to the elongated shape of the AsNB. Apparently, normal faults bound the northern and southern margin, while the eastern slopes of Astypalea Island define the western margin of AsSB. Units from 1 to 4 have been recognized within the sedimentary sequence (Figure 7 ). Unit 1 is a thin layer, about $30 \mathrm{msec}$ thick, of well stratified sediments. A thin layer with an irregular surface and high amplitude, undulating reflectors has been mapped at the base of Unit 1 and has been interpreted as MTD. Unit 2 underlies Unit 1 showing a mean thickness of $50 \mathrm{msec}$ and Unit 3 below, showing a maximum thickness of $120 \mathrm{msec}$. The thickness of the following Unit 4 exceeds the $100 \mathrm{msec}$ close to the southern margin and progressively decreases to the north. The base of Unit 4 shows a rugged morphology. Numerous high angle faults, running E-W, parallel to the basin axis, cross cut the sedimentary sequence of the AsSB. Units 3 and 4 display southward tilting due to the E-W faulting, while the basin as a whole displays maximum subsidence close to its northern margin.

\subsubsection{Kinairos Basin (KB)}

The northeastern part of the survey area is occupied by the Kinairos Basin (KB). The eastern prolongation of Astypalea Ridge separates Kinairos Basin to the North from AsNB to the South. The northern part of Figure 7 illustrates the central part of Kinairos Basin. Seismic Units from 1 to 6 have been mapped within the sedimentary sequence of KB. With the exception of Unit 1, all units show maximum thickness close to the northern faulted margin, indicating rapid subsidence to the north. The thickness of Unit 1 
reaches the 30-40 msec. Unconformity U1 separates Unit 1 from the underlying seismic Unit 2. The maximum thickness of Unit 2 reaches $200 \mathrm{msec}$. A chaotic layer with internal variable amplitude, discontinuous reflectors has been mapped within Unit 2 and has been interpreted due to its geometric characteristics, as MTD. Unit 3 underlies Unit 2 and onlaps unconformity U3. Unit 4 displays seismic character similar to that of Unit 3. However, close to the southern margin, the reflectors become fuzzier and discontinuous. The interface that separates Unit 4 from Unit 5 is not very well illustrated. The attenuation of the seismic signal with depth prevents a detailed description of the nature of unit 6 . However, an upper surface with high amplitude, undulating, discontinuous internal reflectors can be identified. Kinairos Basin displays a dual character. The lower half of the sedimentary sequence (mainly Units 4, 5, and 6) have been tilted and uplifted on the southern margin of the basin to form Astypalea Ridge. Tilting and uplift evolved in parallel with the deposition of the upper half of the basin's infill (Units 3, 2, and 1) and led to the shifting of the depocenter close to the northern faulted margin indicating northward asymmetry of the basin.

\subsection{Seismic Stratigraphy: Ridges}

The Anydros and Astypalea ridges with their splays (AdRa, AdRb, AsRa, and AsRb), as described above, separate the main basins that have been developed in the area. The following is a brief overview of the main features recognized through the interpretation of the seismic stratigraphy of each of them.

\subsubsection{Anydros Ridge (AdRa, AdRb)}

Anydros Ridge is characterized by the occurrence of the uplifted acoustic basement at the seafloor or at a shallow depth below the seafloor. The islet of Anydros, located on the ridge, marks the highest elevated part of the acoustic/alpine basement. The top of the basement displays rugged morphology pointing to subaerial/underwater erosion and faulting (Figures 4 and 5). Indeed, numerous faults cross-cut the southern part of the ridge, close to the margin of Anafi Basin and are responsible for the irregular seafloor. The northeastern part of the ridge is split into two branches (AdRa, AdRb) due to the prolongation of Amorgos Fault (Figure 2). The narrow-elongated valley in between the two branches is thinly sedimented. A narrow, faulted, SW-NE oriented depression occurs at the western part of the ridge and is filled up with sediments of roughly $250 \mathrm{msec}$ thickness (Figure 4). A progadational sequence with characteristic clinoforms occurs in the upper part of the sedimentary infill of the depression, indicating the development of a deltaic sequence, associated with a sea level roughly $400 \mathrm{msec}(300 \mathrm{~m})$ below the present one, during one of the low sea level stages of Quaternary. The sedimentary cover of the northeastern part of AdR mainly consists of sediments of the previously described Units 4 and 5 (Figure 5). Unconformity U3 marks the onset of the uplift of the lower units and the formation of the ridge. Active and apparently normal faults on this part of the ridge create local elevation of the seafloor and deform the sedimentary sequence.

\subsubsection{Astypalea Ridge (AsRa, AsRb)}

The formation of the tectonically controlled Astypalea Ridge (AsR), separates the Amorgos North from Amorgos South and Astypalea basins (Figure 6), the Amorgos South from Astypalea Basin (Figure 6), and the Kinairos from Astypalea Basin (Figure 7). It is divided to the west into two splays, the AsRa and the AsRb (Figure 2). The main body of the ridge is composed of the uplifted, northward tilted sediments of Units 4, 5, and 6 of Amorgos North Basin. Their thickness on the top of AsR exceeds $300 \mathrm{msec}$ in the eastern part and decreases to less than $200 \mathrm{msec}$ below the western part (AsRa, AsRb). As in the Anydros Ridge, Unconformity U3 indicates the onset of the uplift of the lower units of the basins and the formation of the ridge. The uplift of the main ridge and its splays has evolved on the footwall of SE-dipping faults. 


\subsubsection{Akrotiri Ridge (AkR)}

The seismic profiles crossing Akrotiri Ridge show that the latter is free of sedimentary or volcano-sedimentary deposits (Figure 8). The acoustic basement occurs on the rugged seafloor of the ridge and is bounded by steep, SW-NE trending faults. The Akrotiri Fault (Figure 8) controls the northwestern flank of AkR and forms the tectonic boundary with the sedimentary infill of Christiana Basin [77]. Perissa Fault forms the tectonic boundary of the ridge with Anafi Basin. Akrotiri Ridge is the physical prolongation of the southern part of the island of Santorini, where the alpine basement builds Profitis Elias Mountain and outcrops on the steep caldera walls at Athinios port. Therefore, a reasonable hypothesis is that the alpine basement extends southwards and forms the acoustic basement of Akrotiri Ridge.

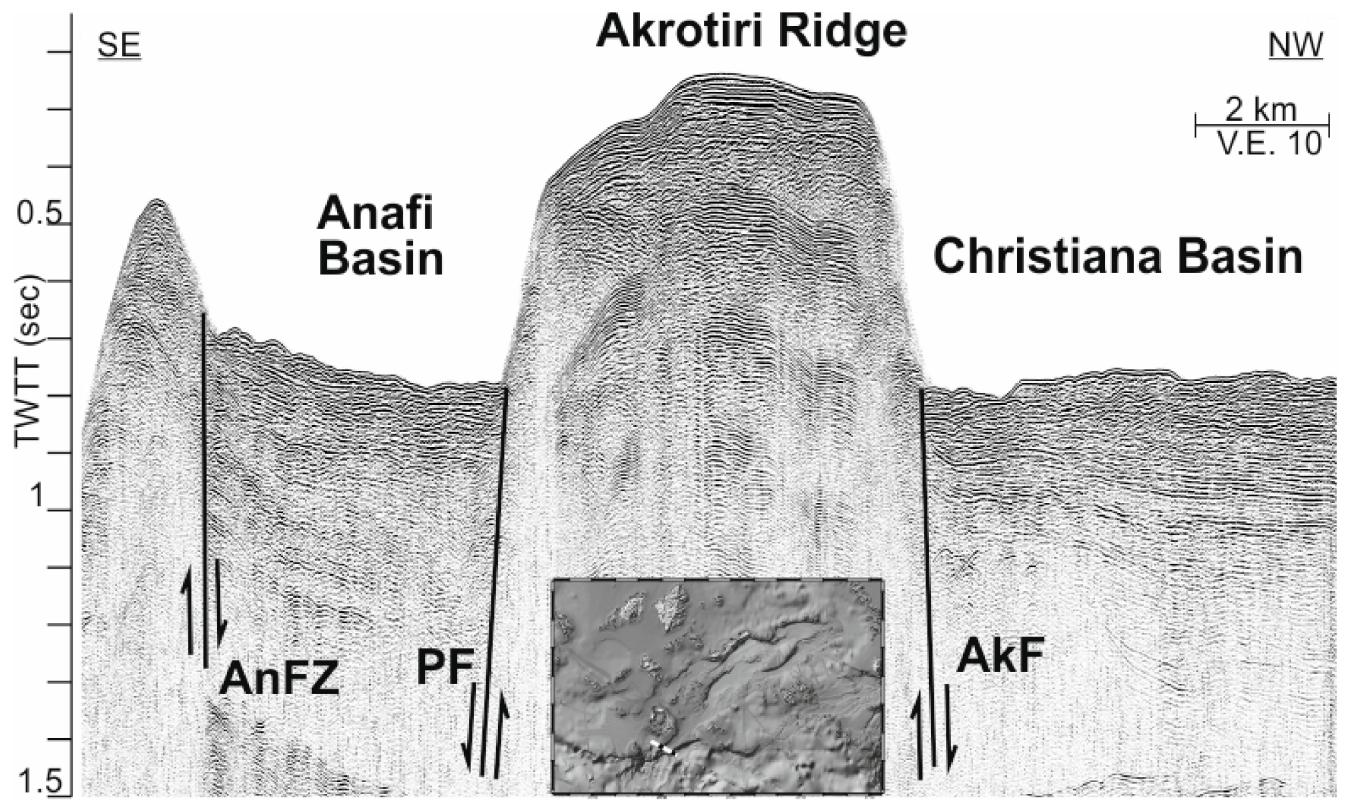

Figure 8. Airgun 40 ci seismic profile crossing the southwestern part of Anafi Basin, Akrotiri Ridge and the southeastern margin of Christiana Basin. AnFZ: Anafi Fault Zone, AkF: Akrotiri Fault, PF: Perissa Fault.

\subsubsection{Anafi Ridge (AnR)}

Anafi Ridge (AnR) is a 30-km long narrow ridge extending from the Island of Anafi towards the SW and forms the southern margin of Anafi Basin's western part. The ridge is not sedimented and the alpine basement that outcrops on the island occurs on the seafloor as acoustic basement.

\subsection{Faulting}

The processing and the interpretation of the seismic profiles, along with the swath bathymetry data, provide sufficient information for the reconstruction of the fault network in the Santorini-Amorgos Shear Zone in unprecedented detail, as well as for the understanding of their evolution and their impact on the evolution of the basins through time. Further on, detailed mapping of the tectonic network, along with the geological-geophysical data and interpretations, provide adequate information which enables the understanding of the style of long-term deformation and kinematics during the Plio-Quaternary.

The geometrical characteristics of each one of the major faults and fault zones are described in detail below, along with their impact on the evolution and structure of the relevant basins. The complete fault network of the Santorini-Amorgos Shear Zone is shown on the tectonic map of Figure 9A. The active fault system indicates that the steep margins of the basins are controlled by mainly NE-SW trending, SE dipping faults and WNW- 
ESE to W-E trending, SSW- or S-dipping, step-over faults. With the exception of western Anydros Basin and Astypalea South Basin, all other basins display northward asymmetry. The maximum thickness of the basin infill, above Unconformity U3, occurs close to the northern marginal faults, while the older seismic units are tilted and uplifted to the South. The latter has resulted in the inversion of the basin's geometry and the formation of the Astypalea and Anydros ridges. Minor intra-basin faults deform the interior of the basins, while pop-up structures, observed in the basins and on the ridges, indicate significant deformation due to horizontal shearing. The proposed kinematics of the individual faults and fault zones and of the entire Santorini-Amorgos Shear Zone is shown on the map of Figure 9B.

\subsubsection{Ios Fault Zone (IFZ) and Amorgos South Relay Fault (ASRF)}

IFZ defines the northern margin of Anydros Basin. It consists of several, observed and possible segments that strike NE-SW, parallel to the long axis of Anydros Basin. It is a $50^{\circ}-65^{\circ} \mathrm{SW}$-dipping fault zone that marks the offshore slopes south of Sikinos and Ios islands to the west and to the northeast terminates at the Amorgos South Relay Fault (ASRF). The southwestern and central parts of Anydros Basin are bounded by the IFZ to the North and the AdRNFZ to the South; they display no tectonic asymmetry and host the volcanic activity of the Christiana-Santorini-Kolumbo chain. The basin infill is cross-cut by SW-NE striking, high angle faults, which may or may not control the occurrence of the volcanic features. Such faults are the ones that create the SW-NE trending "graben" on the northeastern walls of the Santorini caldera and the nearly vertical faults with horizontal striations observed in the area of Koloumbo Cape on Santorini.

Amorgos South Relay Fault (ASRF) is a 15-km long, roughly W-E striking, roughly $60^{\circ}$ S-dipping, apparently normal fault. The orientation of ASRF and its location between the northeastern tip of IFZ and Amorgos Fault indicate that it accommodates the transfer of strain between the SW-NE striking IFZ and AF. ARF marks the northern tectonic boundary of the northeastern part of Anydros Basin. Opposite to the southwestern and central parts, the northeastern one displays northward tectonic asymmetry with ARF driving the enhanced subsidence of the basin floor in its hanging wall. The morphological scarp between the top of South Amorgos Island on the footwall of ARF and the seafloor of the basin is roughly $1 \mathrm{~km}$. The cumulative vertical offset, including the thickness of the basin infill reaches $1.5 \mathrm{~km}$.

\subsubsection{Akrotiri Fault (AkdF) and Anydros Ridge North Fault Zone (AdRNFZ)}

AkF and AdRNFZ constitute the southern tectonic margin of Anydros Basin to Anydros Ridge. They also mark the southern/southeastern limit of the volcanic activity in the Christiana-Santorini-Kolumbo volcanic chain.

Akrotiri Fault $(\mathrm{AkF})$ is 13-km long, and its trace on the seafloor follows the foot of the northwestern slope of Akrotiri Ridge to the Christiana Basin. It strikes SW-NE and dips with a $50^{\circ}-55^{\circ}$ angle to the Northwest. Towards the SW, it terminates at the steep, south-facing margin of the deep Cretan Basin. The NE-ward prolongation of AkF's trace on the island of Santorini coincides with the possible fault that marks the northern limit of the occurrence of the alpine basement on the steep slopes of the caldera in the area of Athinios.

AdRNFZ follows further to the NE with the same SW-NE strike and NW dipping. The part of the fault zone between the eastern slope of Santorini and the islet of Anydros consists of three, en-echelon arranged, SW-NE striking segments. The total length of the three segments reaches $25 \mathrm{~km}$. Further to the NE, the margin of Anydros Basin to Anydros Ridge is cross-cut by a series of E-W striking, N- and S-facing, normal faults. They are en-echelon arranged, each one is less than 5-km long, and they probably represent the NE-ward prolongation of AdRNFZ. The total length of AkF and AdRNFZ is roughly $70 \mathrm{~km}$. 

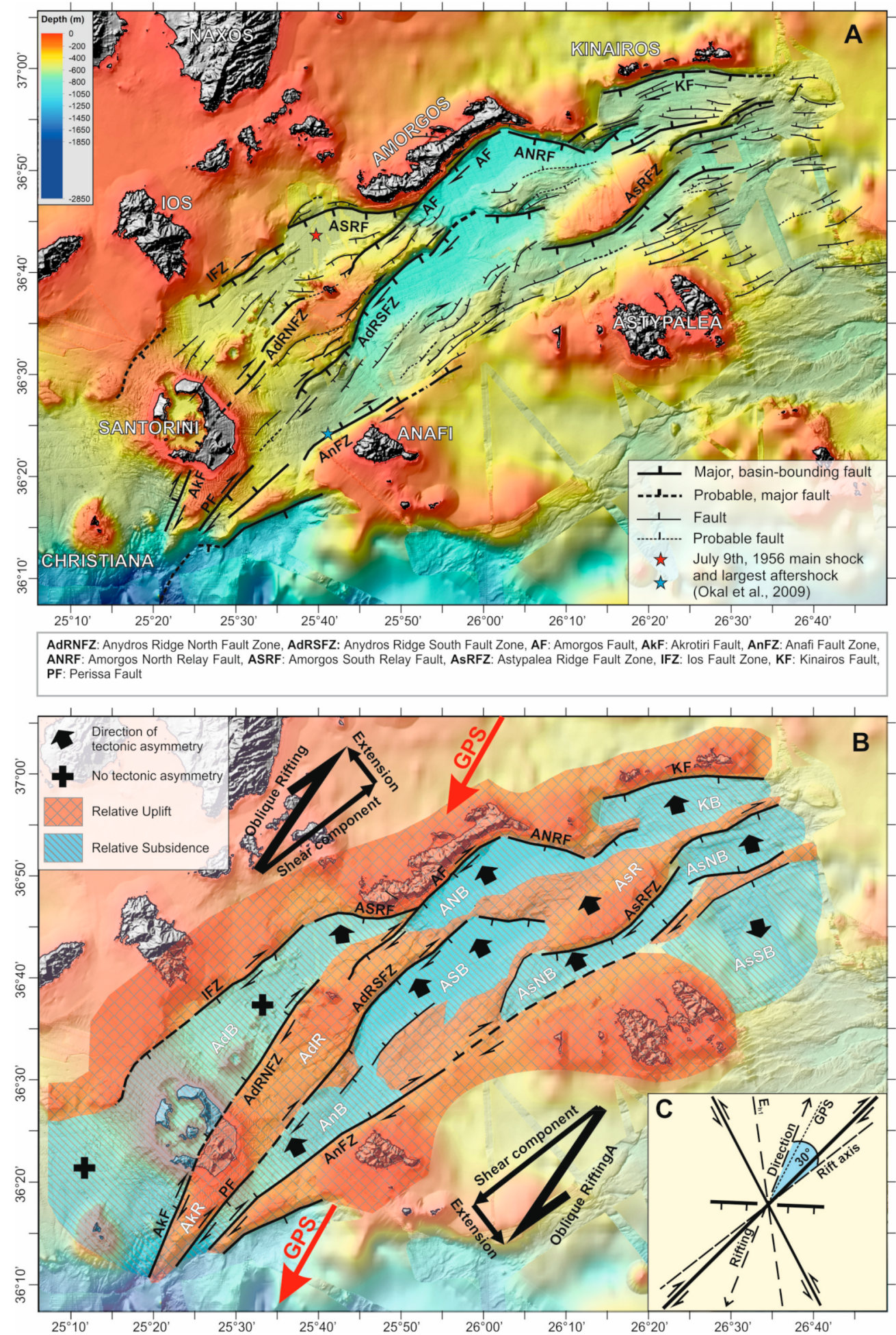

Figure 9. (A): Detailed map of the active fault network in Santorini-Amorgos Shear Zone. Teeth on the faults indicate the downthrown side. Half arrows show the sense of lateral motion. (B): Tectonic and kinematic map of Santorini-Amorgos Shear Zone. Dextral oblique rifting results from dextral strike-slip motion in NE-SW direction and extension in NW-SE direction. Red arrows show the direction of motion in respect to stable Eurasia, modified after Kreemer and Chamot-Rooke [36]. (C): Drawing explaining the kinematic of dextral oblique extension with the rift axis running at $30^{\circ}$ in respect to the rifting direction (modified after Withjack and Jamison, 1986). 


\subsubsection{Perissa Fault (PF) and Anydros Ridge South Fault Zone (AdRSFZ)}

$\mathrm{PF}$ defines the northwestern boundary of Anafi Basin to Akrotiri Ridge. It is a $>15-\mathrm{km}$ long, SW-NE striking fault that dips with a $50^{\circ}-55^{\circ}$ angle to the SE (Figure 8). The height of the morphological scarp, between the seafloor of Anafi Basin and the flat top of Akrotiri Ridge, exceeds $400 \mathrm{~m}$. The cumulative vertical fault offset, including the thickness of the basin infill, exceeds $1 \mathrm{~km}$. Towards the SW, both the fault and Akrotiri Ridge die out at the margin of the deeper Cretan Basin. Chaotic masses of unconsolidated sediments on its hanging wall indicate that the faulted slope has collapsed several times in the past.

AdRSFZ consists of at least three, SE-facing, SW-NE striking segments which mark the southeastern slope of Anydros Ridge and the tectonic and morphological boundary between the latter and the Anafi (AnF) and Amorgos South (ASB) Basins. The total length of AdRSFZ is $45-50 \mathrm{~km}$ and constitutes the northeastern prolongation of Perissa Fault. The two of them can be considered segments of the same fault zone with roughly $80 \mathrm{~km}$ total length. The segments of AdRSFZ dip SE-wards with variable dip values. The southwestern segment dips with roughly $60^{\circ}$, marks the northern margin of Anafi Basin and controls its evolution. The central and northeastern segments dip with $40^{\circ}-45^{\circ}$ and $60^{\circ}$, respectively, and form the northern tectonic boundary of Amorgos South Basin. They form a $>500 \mathrm{~m}$ high morphological scarp between the central part of the ridge and the basin, which decreases towards the NE. The cumulative vertical fault offset, including the thickness of the basin infill, exceeds $1.2 \mathrm{~km}$.

Maximum subsidence in the Amorgos South Basin occurs close to the AdRSFZ northeastern segments and is responsible for the tectonic asymmetry of the basin. The depocenter during the sedimentation of the younger basin infill, above the unconformity U3 (units 3 , 2,1 ), is located very close to the northern margin. The older units, 4, 5, and 6 , below unconformity U3, display constant thickness across the basin and are tilted and uplifted to the south.

The northeastern terminal segment of AdRSFZ marks the boundary of the subsiding Amorgos South Basin with the tilted, uplifted, and inverted southern edge of the Amorgos North Basin, which resulted in the formation of the southern branch of Anydros Ridge. Total vertical offset of 600-700 $\mathrm{m}$ has been measured between the subsided lower units (4, $5,6)$ of Amorgos South Basin and the equivalent units of Amorgos North Basin, which are uplifted on the ridge (Figure 6). The northern edge of AdRF terminates on a WNW-ESE trending normal fault, that controls the uplift of the northern splay of Astypalea Ridge and forms the northeastern boundary of Amorgos South Basin (Figure 9A).

\subsubsection{Amorgos Fault (AF) and Amorgos North Relay Fault (ANRF)}

AF is the most "famous" fault of the study area, as it is responsible for the impressive, steep, rocky, up to $700 \mathrm{~m}$ high southeastern slopes of the island of Amorgos, which continue underwater for another $700 \mathrm{~m}$ before meeting the flat seafloor of Amorgos North Basin. It has been proposed in the literature that AF may has moved during the 9 July 1956, Amorgos earthquake [79] (and references therein). The trace of AF runs along the foot of the subaerial-submarine southeastern slope of Amorgos for roughly $40 \mathrm{~km}$. AF dips with $50^{\circ}$ to $>65^{\circ}$ towards the SE, and its cumulative vertical offset, including the thickness of the infill of Amorgos North Basin (Figure 6), exceeds $2.2 \mathrm{~km}$. The southwestern part of AF prolongs into the Anydros Ridge and divides it into the northern and southern branches. The northeastern part of AF constitutes the diachronic northern tectonic margin of Amorgos North Basin and is responsible for the tectonic asymmetry of the latter. The seismic Units 4, 5, and 6 of Amorgos North Basin display increasing thickness towards AF and are tilted and uplifted on the southern margin. Units 3, 2, and 1, above the Unconformity U3, are deposited unconformably on the previous basin infill; they are not tilted, and their depocenter is close to AF. This observation indicates rapid subsidence close to the northern margin throughout the evolution of ANB. Unconformity U3 marks a major event in the evolution of the basin and may indicate a dramatic change in the activity and/or the kinematics of AF. 
Amorgos North Relay Fault (ANRF) starts from the northeastern tip of AF and prolongs for $15 \mathrm{~km}$ towards the ESE/SE. It dips with $45^{\circ}-50^{\circ} \mathrm{SW}$-wards, defines the northeastern margin of ANB, and separates it through its uplifted footwall from the Kinairos Basin. The cumulative vertical offset of the faults reaches roughly $2.2 \mathrm{~km}$.

Minor intra-basin faults have also been mapped within the basin, but their activity ceased before the deposition of Unit 2. Minor, NW-dipping active faults are observed along the southern margin of ANB to the north splay of Astypalea Ridge.

\subsubsection{Kinairos Fault (KF)}

The structural evolution of Kinairos Basin displays common characteristics with the ANB. The northern marginal fault, referred to as Kinairos Fault (KF), controls the development of the basin. KF is an almost W-E and south-dipping fault $\left(40^{\circ}-50^{\circ}\right)$, with a length of about $25 \mathrm{~km}$. Kinairos and Levitha islets occur on the top of the steep slopes on the footwall of KF. The morphological scarp, produced by the fault, exceeds $600 \mathrm{~m}$, while its cumulative vertical offset of KF, including the thickness of the infill of KB (Figure 7), exceeds $1.5 \mathrm{~km}$. With the exception of Unit 1, the seismic units that constitute the sedimentary infill of $K B$, display maximum thickness close to KF, indicating rapid subsidence to the north. Units 4 and 5 have been tilted and uplifted to the south on the prolongation of Astypalea Ridge, indicating basin inversion. High-angle faults $\left(70^{\circ}-90^{\circ}\right)$ cross-cut the sedimentary infill up to the seafloor. A secondary, N-dipping fault controls the southern margin of KB and contributes to the uplift of the easternmost part of Astypalea Ridge.

\subsubsection{Anafi Fault Zone (AnFZ) and Astypalea Faulted Margin}

AnFZ defines the southern margin of Anafi Basin and strikes NE-SW with $60^{\circ} \mathrm{NW}$ dipping. It ends up on the termination of Anafi Ridge to the southwest, while, to the north-east, it is replaced by a series of minor faults that occur along and form the SWNE trending northern submarine slope off Astypalea Island. The lowermost parts of the sedimentary sequence of Anafi Basin show maximum thickness close to the AnFZ, indicating rapid subsidence during the deposition of Units 5 and 6 . The depocenter of the Anafi Basin was gradually shifted to the North, and the maximum thickness of units 3, 2, and 1 occurs close to the northern tectonic margin (PF and AdRSFZ) of the basin (Figure 4).

Further to the northeast, the southern margin of ASB is controlled by synthetic to AnFZ, NW-dipping faults. These faults, along with high-angle faults that have been mapped on the south and southeastern parts of ASB, deform the oldest parts of the sedimentary sequence (Units 4, 5, and 6). The morphologically smooth transition from Anafi Basin to Amorgos South Basin becomes perceptible on the seismic profile of Figure 10. A small elevation of the acoustic basement separates those two basins. This elevation occurs between two secondary faults that appear inactive during the deposition of Unit 1.

\subsubsection{Astypalea Ridge Fault Zone (AsRFZ)}

AsRFZ is a $65-70-\mathrm{km}$ long fault zone that originates from the Anafi-Astypalea margin, strikes SW-NE and defines the northern margin of Astypalea North Basin (AsNB) against the Amorgos South Basin in the SW, the Astypalea Ridge in the middle, and the Kinairos Basin (KB) in the NE.

The largest segment of AsRFZ controls the SE-facing, steep slope of Astypalea Ridge, is $28-\mathrm{km}$ long, dips with $55^{\circ} \mathrm{SE}$-ward, and marks the major tectonic boundary of Astypalea North Basin. As previously mentioned in Figure 6, the development of AsNB is mainly controlled by the AsRFZ and displays north-ward tectonic asymmetry.

The northeastern segments of AsRFZ are responsible for the uplift and formation of the eastern, narrow part of Astypalea Ridge, which separates AsNB from Kinairos Basin (Figure 7). The southern margin of AsNB is delineated by a $\mathrm{N}$-facing marginal fault that controls the formation of a narrow structural up-lift of the basement and the seafloor that separates AsNB from Astypalea South Basin. The sedimentary infill of AsNB shows maximum thickness at the center of this part of the basin and thins out towards the 
northeastern and southeastern margin. A high angle fault $\left(>82^{\circ}\right)$ crosses the lower parts of the sedimentary sequence without affecting Units 1 and 2 . Secondarily, NE-dipping ( $\left.35^{\circ}\right)$ faults deform the sedimentary sequence close to the SE margin.

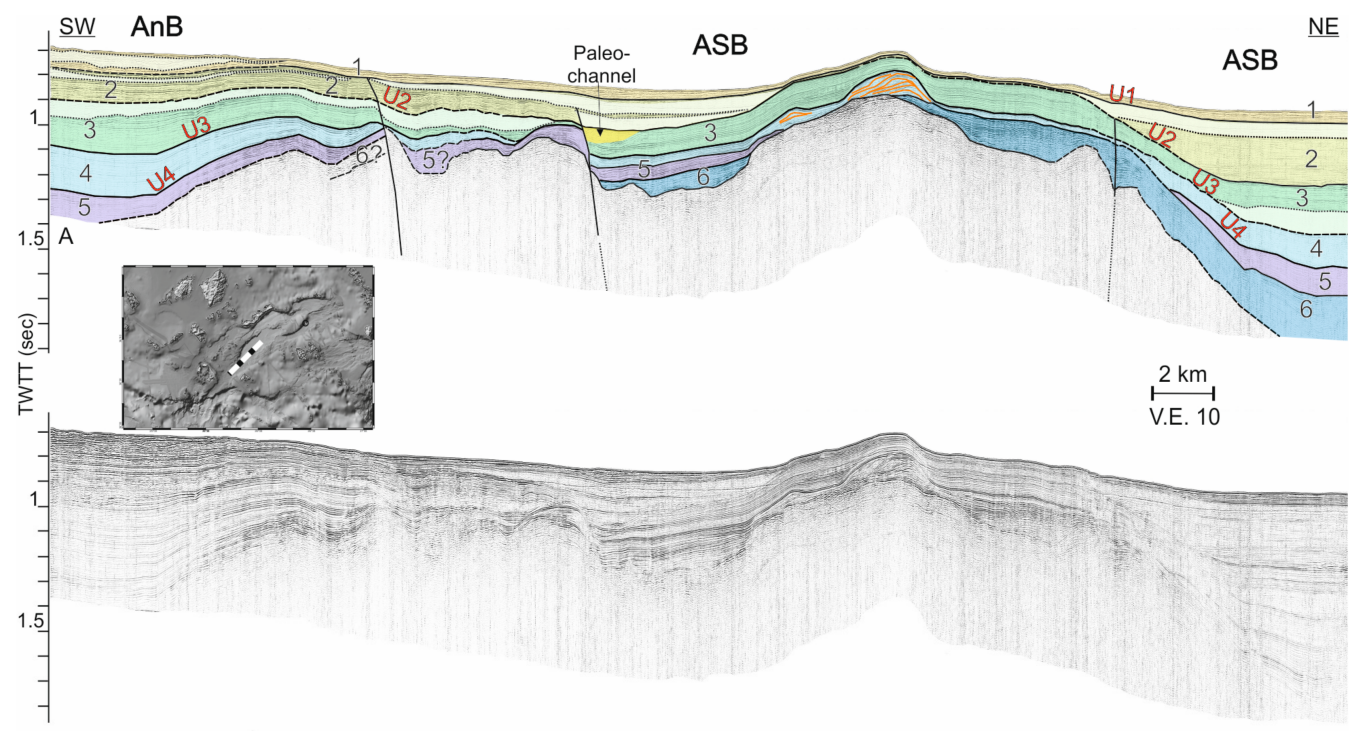

Figure 10. Airgun 40 ci seismic profile along Anafi Basin (AnB) and Amorgos South Basin (ASB) in SW-NE direction (along strike). Terminology and symbols as in Figure 4.

\subsubsection{Astypalea South Basin Faults}

The fault network in AsSB displays interesting differences in respect to the tectonic network of the other basins described so far. AsSB is cross cut by multiple, SW-NE to WSW-ENE striking, high-angle $\left(>50^{\circ}\right)$ faults, which have deformed the sedimentary infill and led to S-ward tilting of the individual tectonic blocks (Figure 7). Within each tectonic block, the thickness of the lower Units 3 and 4 increases from North to South, while the upper Units 2 and 1 display constant more or less thickness with small variations.

This fact indicates rapid subsidence to the south during the deposition of Units 3 and 4 , which was followed by a symmetrical subsidence during the deposition of units 2 and 1 .

\section{Discussion and Synthesis}

The results described above provide insights into the Plio-Quaternary evolution, deformation, and kinematics of Santorini-Amorgos Shear Zone and, hitherto, into the evolution and structure of the South Aegean back arc area. The seismological characteristics of the 1956 Amorgos earthquake are discussed under the light of the present findings.

\subsection{Basin Evolution}

Seven tectonically controlled basins have been mapped and described within SantoriniAmorgos Shear Zone, thus refining and completing our knowledge on the structure of the area. The new data presented here show that the Santorini-Anafi Valley of Perissoratis [61], which has been renamed by Hooft et al. [63] as Anafi Basin and by Nomikou et al. [54] as Santorini-Anafi Basin, is not a single basin; it consists of two different basins, the Anafi Basin and Amorgos South Basin, which display opposite tectonic asymmetry and are separated from each other by a structural high.

Anydros Basin exhibits different geomorphological and geological features in its central-southwestern and northeastern parts, mainly due to active volcanic activity in the southwest and the northward tectonic asymmetry in the northeast. Amorgos North Basin and Amorgos South Basin can be considered as twin basins as they are characterized by identical stratigraphy and tectonic structure. Astypalea North Basin displays different characteristics between the western and eastern parts, with the western part showing 
northward asymmetry and the northeastern part showing a more symmetrical structure. The Astypalea South Basin on the other hand shows southward asymmetry with rapid subsidence of the lowermost parts of the sedimentary sequence close to the southern margin. Furthermore, the northeastern part of SASZ is occupied by the newly described Kinairos Basin, the stratigraphic and tectonic characteristics of which are very similar to the ones of ASB and ANB.

The new data presented here indicate a two-stage structural evolution of the area. The former, single basin has been fractured in Late Pliocene-Early Quaternary by younger, normal to oblique faults. Tectonic activity on the new faults has led to (i) enhanced subsidence on their hanging wall and formation of the present basins and (ii) asymmetric uplift and tilting on their footwall, and creation of ridges that are topped by the uplifted older stratigraphic units of the previous basin. The analysis of the seismic stratigraphy revealed remarkable similarities, as well as certain differences in the sedimentary and tectonic evolution of the basins and ridges. Various minor and major events in the PlioQuaternary tectonic activity in the area have been imprinted on the seismic stratigraphy as minor or major unconformities. Unconformity U3 is the most important among them, since it marks a major change in the evolution of the area, the formation of the ridges and the initiation of new basins.

Perissoratis et al. [70] and Piper and Perissoratis [66] proposed the occurrence of "basin inversion" (uplift of former basinal areas) in the South Aegean. Piper and Perissoratis [66] suggest that "basin inversion" is the result of the change of the strike of the predominant faults from E-W to NE-SW, during the transition from the Pliocene to Quaternary. They also proposed that the deepest seismic units, eastwards of Santorini island, now form prominent ridges. The Unconformity $\mathrm{U} 3$ of the present study seems to be related to the transition from the status of a single basin to a complex regime of individual basins separated by uplifted shallow ridges.

The available data from SASZ do not allow a precise determination of the age of Unconformity U3. Chronological constraints of the post-Messinian infill of sedimentary basins in the Aegean Sea derives (i) either from the interpretation of low sea level prograding sequences and clinoforms or (ii) by comparison with the results of the Deep-Sea Drilling Project (DSDP) hole 378 in the Cretan Sea [67]. The latter penetrated $343.5 \mathrm{~m}$ below the seafloor and revealed two major unconformities: the top of the Messinian evaporites at roughly 305-310 m bsf and a younger one at roughly $130 \mathrm{~m}$ bsf of an Early Quaternary approximate age (also see 77, Figure 6, for a short section of a recent seismic profile through the 378 hole).

The seismic stratigraphy and structure of the sedimentary infill below and above the Early Quaternary unconformity in the Cretan Basin displays remarkable similarities with the seismic stratigraphy of the SASZ basins with the seismic units 6, 5, and 4 below the Unconformity U3 and the seismic units 3, 2, and 1 above it. A similar unconformity has been observed in the sedimentary infill of most of the basins in the South Aegean. It indicates a major change in the tectonic regime with rearrangement and faulting of the Pliocene basins, onset of local subsidence and basin inversion $[43,66,89,90]$. By comparison with the aforementioned data, it is proposed here that Unconformity U3 is equivalent to the Early Quaternary unconformity observed in DSDP hole 378.

The analysis and comparison of the seismic stratigraphy and structure of the seven basins of SASZ indicate that subsidence in the area initiated in the early Pliocene with the formation of one, single basin (Figure 11). The Pliocene basin included the Amorgos North, Amorgos South, Kinairos, the northeastern part of Anydros and probably Anafi basins. The seismic units 6,5, and 4 represent the Pliocene deposits of the lower part of the sedimentary sequences, below Unconformity 3 , in all these basins. The subsidence of the Pliocene basin was controlled predominantly by the northern, E-W to WSW-ENE striking, S-facing, marginal faults. They are the ancestors of the Perissa Fault, Amorgos Fault, and Kinairos Fault. The southern margin was controlled by the early Anafi Fault zone and probably by minor faulting further east. 

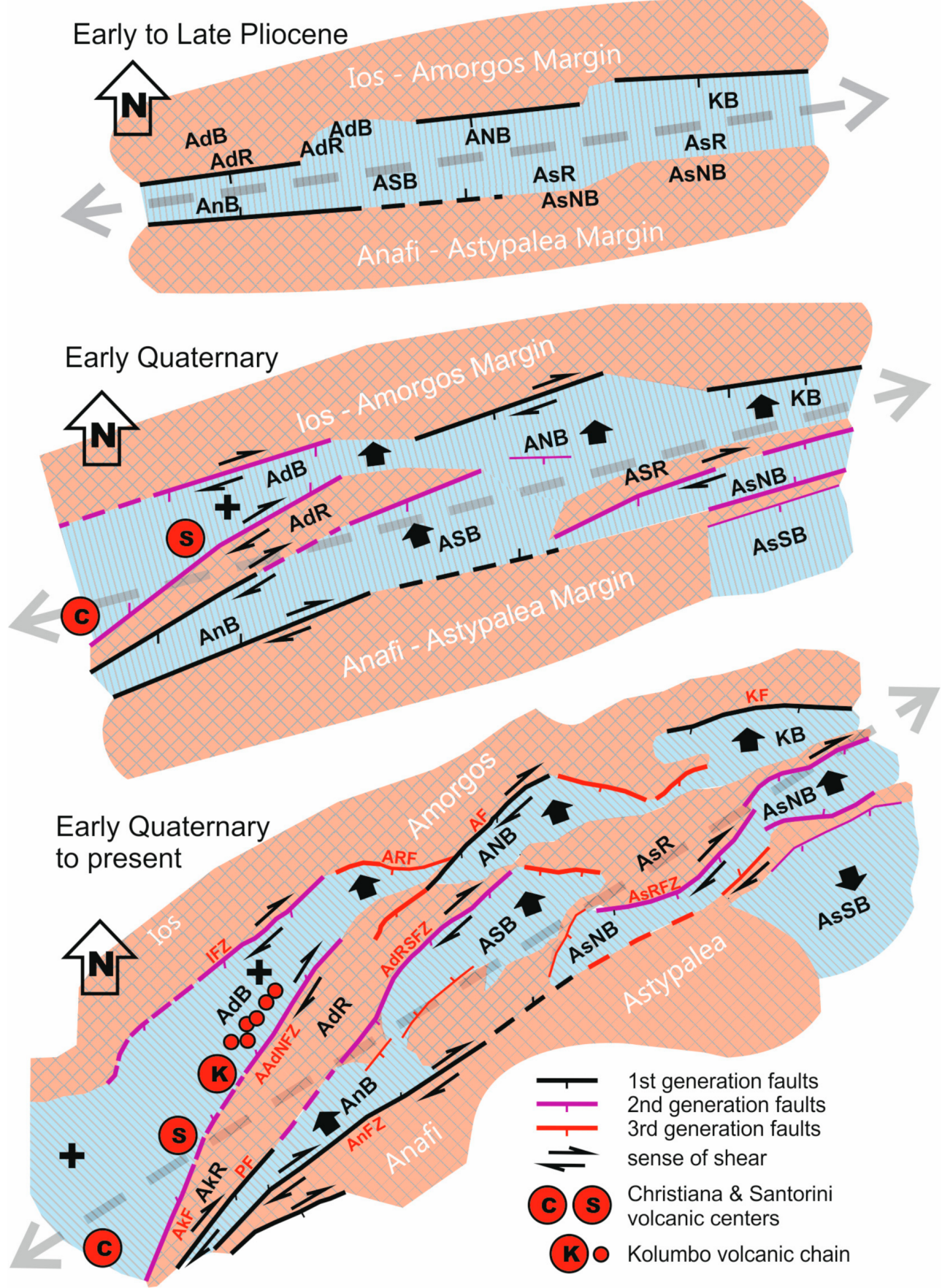

Figure 11. Schematic representation of the evolution of Santorini-Amorgos Shear Zone since Early Pliocene. See text for description and discussion.

The initial, single basin evolved into a significantly more complicated morphological and tectonic structure. Unconformity U3 marks the transition in Early Quaternary from the single basin to the present configuration with the multiple basins and ridges.

The seismic units 6, 5 and partly 4 are absent from the sedimentary sequence of the central and the south-western parts of Anydros Basin and of the Astypalea North and South basins. This evidence strongly suggests that these basins are more recent compared to the other basins of SASZ. Initiation of subsidence and formation of the Astypalea North, Astypalea South, and the central and southwestern part of Anydros Basin took place in the Early Quaternary. They are associated with the Unconformity U3 and are accompanied 
by tilting and uplift of the older basins and the formation of the Anydros and Astypalea Ridges (Figure 11).

Rifting of the southwestern and central parts of Anydros Basin occurred on the northern margin of the Pliocene basin and led to the formation of Anydros Ridge and its separation from the latter. Ios Fault Zone (IFZ) controls the northern margin, while Akrotiri Fault (AkF) and Anydros Ridge North Fault Zone (AdRNFZ) mark the southern boundary of the new basin. The simultaneous initiation of the Anydros Ridge South Fault Zone (AdRSFZ) at the northeastern prolongation of the Perissa Fault (PF) accommodates the uplift of the Anydros Ridge.

Rifting in the Astypalea North Basin occurred in the southeastern part of the Pliocene single basin through the generation of the SE-facing Astypalea Ridge Fault Zone. Uplift of the footwall of the latter resulted to the formation of Astypalea Ridge.

The significant change of the geodynamic regime that led to the re-structuring of the Pliocene single basin and the rifting of new basins in the Early Quaternary, evolved further during the Quaternary and led to the present geological, geomorphological and tectonic configuration of the Santorini-Amorgos Shear Zone. Propagation and re-orientation of the older faults and initiation of new ones accommodated uplift and enlargement of the Anydros and Astypalea Ridges and preferential, localized subsidence in the new basins.

Propagation of the Amorgos Faults (AF) towards the SW and of the Anydros Ridge North and South Fault Zones (AdRNFZ, AdRSFZ) towards the NE resulted in the separation of Amorgos North Basin (ANB) from Amorgos South Basin (ASB) and in the separation of the northeastern part of Anydros Basin from the Amorgos North Basin. Initiation of the WNW-ESE striking Amorgos South Relay Fault (ASRF) led to the asymmetric subsidence in the northeastern part of Anydros Basin. Initiation of the WNW-ESE striking Amorgos North Relay Fault (ANRF), along with the progressive uplift of Astypalea Ridge, led to the separation of Kinairos Basin from Amorgos North Basin. Uplift and bi-directional propagation of the Astypalea Ridge, due to the Astypalea Ridge Fault Zone (AsRFZ), formed the boundary between the Astypalea Basin (AsB) and the Amorgos South Basin (ASB) and between AsB and Kinairos Basin (KB).

The basin evolution model presented above builds on older studies by Piper and Perissoratis (see Reference [66] and Piper et al. [71] in the area extending to the East of Santorini. They have observed a major change of the tectonic regime in the boundary between Pliocene and Quaternary that led from E-W normal faulting to NE strike-slip faulting. Different evolution has been proposed by Hübscher et al. [65] and Nomikou et al. [62]. They have recognized multiple rift pulses in the area between Santorini and Amorgos islands with NE-SW striking normal faults controlling the evolution since Early Pliocene.

\subsection{Deformation and Kinematics}

The detailed map of the active fault network of SASZ is shown in Figure 9A, while the vertical and horizontal sense of movement along the individual faults, the tectonic asymmetry, and vertical movements of the basins and ridges and the kinematic interpretation of the entire structure is illustrated on the sketch-map of Figure 9B.

The fault network is dominated by NE-SW striking, SE-dipping faults and fault zones (IFZ, AF, KF, PF, AdRSFZ, AsRFZ) followed by NW-facing ones (AkF, AdRNFZ, AnFZ). These are the major faults which control the tectonic evolution, shape, subsidence and uplift of the multiple basins and ridges. They are accompanied by roughly W-E (WSW-ENE to WNW-ESE) striking, S-facing normal faults (ASRF, ANRF), which seem to accommodate transfer of strain between the NE-SW striking fault zones.

The NE-SW striking faults are aligned subparallel or at low angle $\left(<20^{\circ}\right)$ to the GPS vectors that show the direction of extension with respect to stable Eurasia [36]. The direction of extension corresponds to the direction of rifting across the SASZ. However, the rifting direction displays angular relationship of roughly $30^{\circ}$ with the orientation of the entire SASZ and with the orientation of the long axes of the basins and ridges that form the latter. The angular relationship between the orientation of SASZ and the rifting direction indicates 
significant obliquity with horizontal and vertical sense of displacement along the marginal, basin bounding faults and fault zones.

The mapped fault network of SASZ (Figure 9A) includes long, NE-SW striking, SEand NW-dipping, steep faults and short, WNW-ESE striking, S-dipping, moderate steep faults. This spatial configuration along with the obliquity between the orientation of SASZ and the rifting direction strongly suggests dextral to dextral oblique sense of movement along the major, NE-SW striking faults. The short WNW-ESE striking faults act as relay, normal faults that accommodate extension and transfer of strain between the former ones. Thus, the deformation of the basins and ridges in the SASZ since Early Quaternary evolved within a complex kinematic regime of dextral obliquity with a NE-SW trending, strike-slip motion associated with local subsidence (basins) and uplift (uplifted sediments, ridges) and extension in NW-SE direction (see Figure 9B). This interpretation is supported by new observations of the GPS velocity field of the Aegean by Briole et al. [41], who recognized dextral transtensional movement of $4.5 \mathrm{~mm} \mathrm{yr}^{-1}$ between the Amorgos and Astypalea islands.

The observed kinematic pattern coincides with the $30^{\circ}$ oblique rifting model of Withjack and Jamison [91], where the basin axis runs at $30^{\circ}$ with respect to the rifting direction (Figure 9C). Their model foresees dextral, strike-slip faults running sub-parallel to the basin axis and normal faults trending about $30^{\circ}$ clockwise with respect to the rift axis. The results obtained from the current study blend in perfectly with this model. The NE-SW faults represent the strike-slip faults running sub-parallel to the basin axis and the WNW-ESE striking faults coincide to the extensional step over normal faults.

The interpretation of the style of deformation and the kinematic pattern in the Santorini-Amorgos Shear Zone, as described here above, takes advantage of and builds on previous studies that have contributed to the understanding of the structure and tectonics of this part of the Aegean Sea.

Dextral strike-slip faulting in NE-SW direction has been firstly proposed in the 90s by Mascle, Martin [43] for the Santorini-Amorgos area and other areas in the Aegean. Papadopoulos and Pavlidis [59] have suggested normal faulting with a significant rightlateral, strike-slip component in the area. The conclusion of Stiros et al. [92] was that Amorgos can be regarded as the uplifted and back-tilted footwall of a major normal fault or that the island marks the restraining (and uplifting) bend of the oblique-slip fault that controls its southeastern coast. Piper and Perissoratis [66] and Piper et al. [71] proposed that the style of the NE-SW faulting observed in the area east of Santorini Island, strongly suggest a strike-slip regime. The micro-seismicity data presented by Bohnhoff et al. [48] have shown that the SW-NE Santorini-Amorgos zone is in the state of a right-lateral transtension. This observation has been reinforced by Dimitriadis et al. [74]. Sakellariou et al. [64] proposed that both Thera and Kolumbo volcanic centers occur within the NE-SW-trending Anydros graben, which constitutes a negative flower structure related to a $40 \mathrm{~km}$, possibly dextral, strike-slip zone, the Kameni-Kolumbo strike-slip, which can be extended SW-wards to the Christiana volcanic island. Analysis and relocation of the 2011-2012 seismic crisis in Santorini Caldera by Papadimitriou et al. [76] showed that the seismicity was NE-SW oriented with focal mechanisms, indicating dextral strike-slip faulting. Tsampouraki-Kraounaki and Sakellariou [73] suggested that the NE-SW-trending, morphologically complex area northeast of Thera until the islands of Amorgos, Astypalea and Kalymnos, which encompasses Anydhros Basin and the six sub-basins of Amorgos Basin undergoes dextral transtensional deformation accommodated by NE-SW strikeslip to oblique faults and E-W normal step-over faults. Sakellariou and TsampourakiKraounaki [42] have refined the offshore fault network and the kinematics of the Aegean Sea. They proposed that deformation is dominated by dextral shear zones in the northern, central, and southwestern Aegean and by sinistral shear zones in the southeastern Aegean. The Santorini-Amorgos Shear Zone displays a dextral sense of movement and marks the boundary between the dextral and sinistral shearing.

Opposite to the dextral sense of shearing described above, Hübscher et al. [65], Nomikou et al. [54,62], and Hooft et al. [63] have suggested that normal faulting is the 
main tectonic mechanism controlling the formation and evolution of the Anydhros Basin and the Thera-Amorgos area. Nomikou et al. [62] stated that normal NE-SW striking, SE-dipping faulting is the superior mechanism forming the present horst and graben structures in the Santorini-Amorgos area, even though they have recognized an additional strike-slip component. A different interpretation has been recently proposed by Tzanis et al. [78]. The authors studied the kinematic regime of the Santorini area by using gravity, magnetotelluric, and DGPS data. According to their interpretation, the kinematic regime in that area is characterized by NW-SE dextral strike slip faults and NE-SW normal to sinistral faults generated by N-S oriented $\sigma 1$ and E-W oriented $\sigma 3$. However, the marine geophysical data presented here, as well as the seismological data available in previous studies, do not support sinistral sense of slip along the NE-SW striking faults of the area. In addition, the dextral transtensional movement of $4.5 \mathrm{~mm}$ yr-1 between the Amorgos and Astypalea islands, observed by Briole et al. [41], strongly support significant dextral sense of horizontal slip along the SASZ, as proposed in the current work.

\subsection{The Amorgos 1956 Earthquake}

The focal mechanism, epicenter, and magnitude of the 9 July 1956, "Amorgos Earthquake", the largest seismic event in the Aegean Sea in the 20th century, have been the subject of many studies with contradicting results. The magnitude of the earthquake varies between M: 7.5 [81,93-96], M: 7.6 [97], and M: 7.8 [79], while the magnitude of the largest aftershock, that followed 12 min after the main shock, has been estimated to M: 7.2 [79]. The focal mechanisms proposed so far are different from each other. Papazachos and Delibassis [81] and Ritsema [82] have suggested strike-slip movement along NE-SW striking, SE-dipping fault, while Shirokova [80] proposed a normal faulting geometry. Konstantinou [97] and Okal et al. [79] proposed normal faulting on a fault dipping gently to the SSE (see Reference [79] for a thorough discussion). Brústle et al. [83] proposed that the focal mechanism of the first event indicates normal slip with minor dextral motion on a SW-NE striking SE dipping fault plane $\left(\varphi=36^{\circ}, \delta=62^{\circ} / 67^{\circ}, \lambda=-96^{\circ} /-108^{\circ}\right)$ at a depth of $25 \pm 5 \mathrm{~km}$. They also confirm that the focal mechanism is consistent with the location of the epicenter on the northern flank of the Santorini-Amorgos graben. It is commonly accepted (but not proved with field data) that the Amorgos Fault is related with and moved during the 1956 earthquake.

The epicenters calculated by the various studies for the main shock fall within an area a few tens of kilometers wide, west and southwest of the island of Amorgos. The epicenters of the main shock and of the largest aftershock, with the coordinates calculated by Okal et al. [79] are shown on the map of Figure 9A. The epicenter of the main shock [79] falls within the northeastern part of Anydros Basin, on the footwall of Amorgos Fault and roughly 8-9 $\mathrm{km}$ northwest from its trace. If the location of the epicenter and the normal-slip focal mechanism are correct, it is highly unlikely that the earthquake moved the SE-dipping Amorgos Fault, as in this case it should be located on the hanging wall of the fault. In that case, the main shock may be associated with one of the faults that define the northern margin of Anydhros Basin. Alternatively, if the strike-slip focal mechanism on the NE-SW striking plane is the correct one for the main shock, it may fit with dextral slip on Amorgos Fault.

\subsection{Implications for the Plio-Quaternary Evolution of the South Aegean back-arc}

It has been previously shown that the change in the mode of deformation is related with the Unconformity U3, which marks the transition from the extensional, Pliocene single basin to the Quaternary multi-basin dextral shear zone, and that U3 can be correlated with the Early Quaternary unconformity observed in DSDP hole 378 in the Cretan Sea [67].

Several seismic profiling surveys conducted in the South Aegean Sea since the 80s (see References $[43,66,77,89,90,98]$ and others) have provided significant information on the evolution and structure of the sedimentary basins (Myrtoon, Maleas, Chania, Heraklion, Christiana, Kamilonissi, Karpathos Basins, Figure 1). A major unconformity M marks the 
top of Messinian occurrences throughout the South Aegean. It represents the erosional surface of the exposed basement below the margins and the top of the Messinian evaporites below the basins. A second, widespread unconformity has been observed in the sedimentary infill of most of the basins in the South Aegean and has been correlated with the Early Quaternary unconformity observed in the DSDP 378 drill hole in the Cretan Basin [67]. It marks a major change in the tectonic regime, which led to rearrangement and faulting of the Pliocene basins, tilting of the basins' infill, local subsidence, and/or uplift and the development of the present morphological structure (see References $[43,66,77,89,90,98]$, and others).

The similarities between the structural characteristics of the South Aegean basins with the SASZ basins presented in this work are sound and point to a comparable structural evolution during the Plio-Quaternary. The evolution of SASZ from a single, E-W oriented, extensional basin in the Pliocene to the present, SW-NE striking, structurally complicated zone of dextral shearing and oblique rifting, composed of multiple basins and ridges, follows the progressive stretching of the South Aegean back-arc area towards SSW. The presumably Early Quaternary age of Unconformity U3 provides chronological constrains for the transition from N-S directed extension to NE-SW oriented dextral shearing.

A similar change in the style of deformation and basin evolution in the South Aegean Sea is strongly indicated by the available literature data described previously. Consequently, it is proposed here that the entire South Aegean back arc area has been affected in the Early Quaternary by a major change of the geodynamic regime that led to the formation of the present geomorphological configuration and structure. Large, mostly W-E oriented basins may have dominated the area between the Cyclades Plateau to the North and the Hellenic Arc to the South during the Pliocene. The Early Quaternary unconformity observed in most of the basins marks the transition from N-S extension, accommodated by mostly W-E normal faulting, to a new kinematic pattern composed mainly of NESW and NW-SE conjugate, strike-slip to oblique faulting and secondary W-E faults (see References [42,43]. Subsequent deformation and fracturing of the Pliocene large basins led to enhanced subsidence in smaller basins, uplift and inversion of the previous basin infill and creation of new structural highs and ridges.

Back arc extension in the Aegean initiated in the Middle Eocene and is since then driven by the roll-back of the subducting East Mediterranean slab and the advancement of the trench towards the south [2,99-105]. The velocity of the trench retreat was less than $1 \mathrm{~cm} / \mathrm{y}$ until the Middle Miocene and accelerated progressively to reach $3.2 \mathrm{~cm} / \mathrm{y}$ in the Plio-Quaternary [1], while, according to Beniest et al. [106], it accelerated by a factor of 5 after the Pliocene. Roll back and trench retreat led to a progressive increase of the curvature of the Hellenic Arc, re-organization of the crustal extension in the South Aegean back-arc area, re-orientation of older faults and initiation of new ones that deformed the older basins and led to extensive new basin and ridge formation.

The arrival and propagation of the North Anatolian Fault (NAF) in the North Aegean added one more factor of complexity. It is not yet adequately understood if and how the NAF interacts with the roll back and the trench retreat and how their interplay affects the evolution and deformation of the Aegean back arc since the arrival of the former. Armijo et al. [3,4] were the first to propose that NAF propagated in the North Aegean in Late Miocene to Early Pliocene, at roughly $5 \mathrm{Ma}$ BP and triggered the initiation and development of the major grabens in the Corinth, North Evia, and Thermaikos Gulfs. However, more recent studies propose that NAF may have arrived in the Aegean in the Early Pleistocene, at 2 Ma BP [107], or Early to Middle Pleistocene [106] or even earlier, at $430 \mathrm{ka}$ BP [108]. Beniest et al. [106] suggested that the establishment of NAF in the North Aegean Sea in the Lower to Middle Pleistocene may be responsible for the acceleration of the trench retreat and increase of its curvature after the Pliocene.

The presumably Early Quaternary in age Unconformity U3 in the SASZ and its correlation with the equivalent unconformity observed in the basins of the South Aegean indicate a drastic change in the basin evolution and mode of deformation. Enhanced 
shearing and oblique rifting along the SASZ and probably widely in the South Aegean are the results of the change in the angular relationship between the orientation of the rifted basins and the kinematic regime. It is proposed here that the establishment of the Early Quaternary to present kinematic regime has been triggered by the gradual propagation in the North Aegean and the onset of interaction between the NAF and the trench retreat.

To confirm the above hypothesis and to gain reliable chronological constraints on the evolution and style of the deformation in the South Aegean Sea back arc area, further systematic swath bathymetry and seismic profiling surveys are needed. As already stated, most of the South Aegean Sea is either not surveyed at all or covered by sparse and old data of limited use. The significant lack of data leaves many open questions on the basin evolution, the style of deformation, and the kinematic regime.

\section{Conclusions}

Processing, analysis, and interpretation of systematic swath bathymetry and seismic profiling data obtained during several cruises on the R/V AEGAEO of the Hellenic Center for Marine Research between 2001 and 2017 in the broader area between Santorini, Amorgos, Kalymnos, Astypalea, and Anafi Islands in the South Aegean Sea, Greece, lead to the following major conclusions.

Santorini-Amorgos Shear Zone (SASZ) is a NE-SW striking, dextral shear, and oblique rifting zone. It includes seven, actively subsiding, elongated or spindle-shaped basins (Anydros, Anafi, Amorgos South, Amorgos North, Kinairos, Astypalea North and Astypalea South Basins), two actively uplifting, shallow ridges (Anydros and Astypalea Ridges), and several branches formed in the prolongations of the ridges. Dextral shearing and oblique rifting are accommodated by NE-SW oblique faults and fault zones, running at a low angle with respect to the NNE-SSW oriented kinematic vectors, and by roughly W-E striking, normal, transfer faults. The active fault pattern and kinematics is compatible with dextral oblique rifting across a rift zone oriented at roughly $30^{\circ}$ in respect to the rifting direction. The axis of SASZ strikes $\mathrm{N} 50^{\circ}-55^{\circ} \mathrm{E}$, while the GPS derived kinematic vectors that indicate the rifting direction are oriented at $\mathrm{N} 25^{\circ}-30^{\circ} \mathrm{E}$.

The SASZ initiated in the Early Pliocene as a single, W-E oriented, extensional basin developed within a N-S directed extensional regime. The sediments deposited during Pliocene represent the lower part of the sedimentary sequences of the Anafi, Amorgos South, Amorgos North, and Kinairos basins, which were united into a single basin. A major reorganization of the geodynamic and kinematic regime took place sometime in the Early Quaternary and was imprinted in the seismic stratigraphy of the above basins with the Unconformity U3. It led to reorientation of the older faults and initiation of new ones striking NE-SW, disruption of the former single basin with local subsidence creating four new depocenters (basins) and local uplift, and rifting of the northern and southern Pliocene margins, formation of the Anydros, Astypalea North, and Astypalea South basins and of the Anydros and Astypalea ridges.

The apparent discrepancy between the dip-slip normal focal mechanism modeled for the 9 July 1956, Amorgos earthquake and the dextral shearing kinematics attributed to the SASZ is being discussed. It is proposed here that the normal faulting focal mechanism on a fault dipping to the SSE, proposed by Okal et al. [76], is compatible with the geometry and kinematic characteristics of the W-E striking Amorgos South Relay Fault (ASRF) and can be explained within the dextral strike-slip regime of the SASZ.

Comparison of the seismic stratigraphy, evolution and structure of SASZ and of the basins of the South Aegean, indicates that the entire area has been affected by a major change of the kinematic regime. Enhanced shearing and oblique rifting along the SASZ and probably in the entire South Aegean back arc area is the result of the change of the angular relationship between the orientation of the rifted basins and the kinematic regime. It is proposed here that the establishment of the Early Quaternary to present kinematic regime has been triggered by the gradual propagation of the North Anatolian Fault in the North Aegean and the onset of interaction with the trench retreat since the Early Quaternary. 
Author Contributions: Conceptualization, K.T.-K., D.S.; methodology, K.T.-K., D.S., I.M., I.L., I.P.; data acquisition, D.S., G.R., K.T.-K., I.M., I.L., I.P., K.M.; software, I.M., I.L., I.P., K.T.-K., D.S.; validation, all authors; formal analysis, all authors.; investigation, K.T.-K., D.S.; resources, D.S., G.R.; data curation, K.T.-K., D.S., I.M., I.L.; writing—original draft preparation, K.T.-K., D.S., F.P.; writing一review and editing, all authors; visualization, K.T.-K., D.S.; supervision, D.S., G.P., F.P.; funding acquisition, D.S., F.P. All authors have read and agreed to the published version of the manuscript.

Funding: This research received no external funding.

Institutional Review Board Statement: Not applicable.

Informed Consent Statement: Not applicable.

Data Availability Statement: Swath bathymetry data presented here are available through the EMODnet Bathymetry portal (emodnet.eu/bathymetry). Seismic profiling data are archived in HCMR's data base.

Acknowledgments: This work uses swath bathymetry and seismic profiling data acquired during several cruises of R/V AEGAEO between 2001 and 2017 and funded partly by THERA (2006) and Eurofleets2 LGT-AMORGOS-56 international projects and partly by national (HCMR) funds. The authors are grateful to the colleagues and technicians who contributed to the acquisition of the data. The crew and the captain of R/V AEGAEO are particularly acknowledged for their continuous support and smooth collaboration during the cruises. We would like to thank Emeritus Professor J. Mascle for the valuable discussions we had with him at the early stage of the preparation of the manuscript. Last but not least, we are grateful to the reviewers for the critical and constructive review of the manuscript.

Conflicts of Interest: The authors declare no conflict of interest.

\section{References}

1. Brun, J.-P.; Faccenna, C.; Gueydan, F.; Sokoutis, D.; Philippon, M.; Kydonakis, K.; Gorini, C. The two-stage Aegean extension, from localized to distributed, a result of slab rollback acceleration. Can. J. Earth Sci. 2016, 53, 1142-1157. [CrossRef]

2. Jolivet, L.; Faccenna, C.; Huet, B.; Labrousse, L.; Le Pourhiet, L.; Lacombe, O.; Lecomte, E.; Burov, E.; Denèle, Y.; Brun, J.-P.; et al. Aegean tectonics: Strain localisation, slab tearing and trench retreat. Tectonophysics 2013, 597-598, 1-33. [CrossRef]

3. Armijo, R.; Meyer, B.; King, G.C.P.; Rigo, A.; Papanastassiou, D. Quaternary evolution of the Corinth Rift and its implications for the Late Cenozoic evolution of the Aegean. Geophys. J. Int. 1996, 126, 11-53. [CrossRef]

4. Armijo, R.; Meyer, B.; Hubert, A.; Barka, A. Westward propagation of the North Anatolian fault into the northern Aegean: Timing and kinematics. Geology 1999, 27, 267-270. [CrossRef]

5. Reilinger, R.; McClusky, S.; Paradissis, D.; Ergintav, S.; Vernant, P. Geodetic constraints on the tectonic evolution of the Aegean region and strain accumulation along the Hellenic subduction zone. Tectonophysics 2010, 488, 22-30. [CrossRef]

6. McKenzie, D. Active Tectonics of the Mediterranean Region. Geophys. J. Int. 1972, 30, 109-185. [CrossRef]

7. McKenzie, D. Active tectonics of the Alpine-Himalayan belt: The Aegean Sea and surrounding regions. Geophys. J. Int. 1978, 55, 217-254. [CrossRef]

8. Le Pichon, X.; Angelier, J. The hellenic arc and trench system: A key to the neotectonic evolution of the eastern mediterranean area. Tectonophysics 1979, 60, 1-42. [CrossRef]

9. Dewey, J.F.; Şengor, A.M.C. Aegean and surrounding regions: Complex multiplate and continuum tectonics in a convergent zone. Geol. Soc. Am. Bull. 1979, 90, 84-92. [CrossRef]

10. Pichon, X.L.; Angelier, J.; Osmaston, M.F.; Stegena, L. The Aegean Sea. Philos. Trans. R. Soc. London. Ser. A, Math. Phys. Sci. 1981, 300, 357-372. [CrossRef]

11. Angelier, J.; Lybéris, N.; Le Pichon, X.; Barrier, E.; Huchon, P. The tectonic development of the hellenic arc and the sea of crete: A synthesis. Tectonophysics 1982, 86, 159-196. [CrossRef]

12. Le Pichon, X.; Angelier, J.; Sibuet, J.-C. Plate boundaries and extensional tectonics. Tectonophysics 1982, 81, 239-256. [CrossRef]

13. Le Pichon, X. Land-locked oceanic basins and continental collision: The Eastern Mediterranean as a case example. In Symposium on Mountain Building; Hsu, K.J., Ed.; Academic Press: San Diego, CA, USA, 1983; pp. 201-211.

14. McKenzie, D.; Jackson, J. A block model of distributed deformation by faulting. J. Geol. Soc. 1986, 143, 349-353. [CrossRef]

15. Jackson, J.; McKenzie, D. Rates of active deformation in the Aegean Sea and surrounding regions. Basin Res. 2007, 1, 121-128. [CrossRef]

16. Taymaz, T.; Jackson, J.; McKenzie, D. Active tectonics of the north and central Aegean Sea. Geophys. J. Int. 1991, 106, 433-490. [CrossRef]

17. Jackson, J. Active Tectonics of the Aegean Region. Annu. Rev. Earth Planet. Sci. 1994, 22, 239-271. [CrossRef]

18. Papazachos, C.B.; Kiratzi, A.A. A detailed study of the active crustal deformation in the Aegean and surrounding area. Tectonophysics 1996, 253, 129-153. [CrossRef] 
19. Papazachos, B.C.; Papadimitriou, E.E.; Kiratzi, A.A.; Papazachos, C.B.; Louvari, E.K. Fault plane solutions in the Aegean Sea and the surrounding area and their tectonic implication. Boll. Geofis. Teor. Appl. 1998, 39, 199-218.

20. Goldsworthy, M.; Jackson, J.; Haines, J. The continuity of active fault systems in Greece. Geophys. J. Int. 2002, 148, 596-618. [CrossRef]

21. Kiratzi, A. Focal mechanisms of shallow earthquakes in the Aegean Sea and the surrounding lands determined by waveform modelling: A new database. J. Geodyn. 2003, 36, 251-274. [CrossRef]

22. Kokkalas, S.; Xypolias, P.; Koukouvelas, I.; Doutsos, T. Postcollisional contractional and extensional deformation in the Aegean region. In Post-Collisional Tectonics and Magmatism in the Mediterranean Region and Asia: Geological Society of America Special Paper; Dilek, Y., Pavlides, S., Eds.; Geological Society of America: Boulder, CO, USA,2006; Volume 409, pp. 97-123. [CrossRef]

23. Chatzipetros, A.; Kiratzi, A.; Sboras, S.; Zouros, N.; Pavlides, S. Active faulting in the north-eastern Aegean Sea Islands. Tectonophysics 2013, 597-598, 106-122. [CrossRef]

24. Billiris, H.; Paradissis, D.; Veis, G.; England, P.; Featherstone, W.; Parsons, B.; Cross, P.; Rands, P.; Rayson, M.; Sellers, P.; et al. Geodetic determination of tectonic deformation in central Greece from 1900 to 1988. Nat. Cell Biol. 1991, 350, 124-129. [CrossRef]

25. Contributions of Space Geodesy to Geodynamics: Crustal Dynamics. In The Core-Mantle Boundary Region; American Geophysical Union (AGU): Washington, WA, USA, 1993; pp. 331-346.

26. Straub, C.; Kahle, H.-G. Global Positioning System (GPS) estimates of crustal deformation in the Marmara Sea region, Northwestern Anatolia. Earth Planet. Sci. Lett. 1994, 121, 495-502. [CrossRef]

27. Kahle, H.-G.; Müller, M.V.; Geiger, A.; Danuser, G.; Mueller, S.; Veis, G.; Billiris, H.; Paradissis, D. The strain field in northwestern Greece and the Ionian Islands: Results inferred from GPS measurements. Tectonophysics 1995, 249, 41-52. [CrossRef]

28. Le Pichon, X.; Chamot-Rooke, N.; Lallemant, S.; Noomen, R.; Veis, G. Geodetic determination of the kinematics of central Greece with respect to Europe: Implications for eastern Mediterranean tectonics. J. Geophys. Res. Space Phys. 1995, 100, 12675-12690. [CrossRef]

29. Davies, R.; England, P.; Parsons, B.; Billiris, H.; Paradissis, D.; Veis, G. Geodetic strain of Greece in the interval 1892-1992. J. Geophys. Res. Space Phys. 1997, 102, 24571-24588. [CrossRef]

30. Reilinger, R.E.; McClusky, S.C.; Oral, M.B.; King, R.W.; Toksoz, M.N.; Barka, A.A.; Kinik, I.; Lenk, O.; Sanli, I. Global Positioning System measurements of present-day crustal movements in the Arabia-Africa-Eurasia plate collision zone. J. Geophys. Res. Space Phys. 1997, 102, 9983-9999. [CrossRef]

31. Clarke, P.J.; Billiris, H.; Paradissis, D.; Veis, G.; Cross, P.A.; Denys, P.H.; Ashkenazi, V.; Kahle, H.-G.; Muller, M.-V.; Davies, R.R.; et al. Crustal strain in central Greece from repeated GPS measurements in the interval 1989-1997. Geophys. J. Int. 1998, 135, 195-214. [CrossRef]

32. Cocard, M.; Kahle, H.-G.; Peter, Y.; Geiger, A.; Veis, G.; Felekis, S.; Paradissis, D.; Billiris, H. New constraints on the rapid crustal motion of the Aegean region: Recent results inferred from GPS measurements (1993-1998) across the West Hellenic Arc, Greece. Earth Planet. Sci. Lett. 1999, 172, 39-47. [CrossRef]

33. Kahle, H.-G.; Cocard, M.; Peter, Y.; Geiger, A.; Reilinger, R.; Barka, A.; Veis, G. GPS-derived strain rate field within the boundary zones of the Eurasian, African, and Arabian Plates. J. Geophys. Res. Space Phys. 2000, 105, 23353-23370. [CrossRef]

34. Briole, P.; Rigo, A.; Lyon-Caen, H.; Ruegg, J.C.; Papazissi, K.; Mitsakaki, C.; Balodimou, A.; Veis, G.; Hatzfeld, D.; Deschamps, A. Active deformation of the Corinth rift, Greece: Results from repeated Global Positioning System surveys between 1990 and 1995. J. Geophys. Res. Space Phys. 2000, 105, 25605-25625. [CrossRef]

35. McClusky, S.; Balassanian, S.; Barka, A.; Demir, C.; Ergintav, S.; Georgiev, I.; Gurkan, O.; Hamburger, M.; Hurst, K.; Kahle, H.; et al. Global Positioning System constraints on plate kinematics and dynamics in the eastern Mediterranean and Caucasus. J. Geophys. Res. Space Phys. 2000, 105, 5695-5719. [CrossRef]

36. Kreemer, C.; Chamot-Rooke, N.; Lepichon, X. Constraints on the evolution and vertical coherency of deformation in the Northern Aegean from a comparison of geodetic, geologic and seismologic data. Earth Planet. Sci. Lett. 2004, 225, 329-346. [CrossRef]

37. Nyst, M.; Thatcher, W. New constraints on the active tectonic deformation of the Aegean. J. Geophys. Res. Space Phys. 2004, 109, 1-23. [CrossRef]

38. Reilinger, R.; McClusky, S.; Vernant, P.; Lawrence, S.; Ergintav, S.; Cakmak, R.; Ozener, H.; Kadirov, F.; Guliev, I.; Stepanyan, R.; et al. GPS constraints on continental deformation in the Africa-Arabia-Eurasia continental collision zone and implications for the dynamics of plate interactions. J. Geophys. Res. Space Phys. 2006, 111, 1-26. [CrossRef]

39. Pérouse, E.; Chamot-Rooke, N.; Rabaute, A.; Briole, P.; Jouanne, F.; Georgiev, I.; Dimitrov, D. Bridging onshore and offshore present-day kinematics of central and eastern Mediterranean: Implications for crustal dynamics and mantle flow. Geochem. Geophys. Geosyst. 2012, 13, 1-25. [CrossRef]

40. Kassaras, I.; Kapetanidis, V.; Ganas, A.; Tzanis, A.; Kosma, C.; Karakonstantis, A.; Valkaniotis, S.; Chailas, S.; Kouskouna, V.; Papadimitriou, P. The New Seismotectonic Atlas of Greece (v1.0) and Its Implementation. Geosciences 2020, 10, 447. [CrossRef]

41. Briole, P.; Ganas, A.; Elias, P.; Dimitrov, D. The GPS velocity field of the Aegean. New observations, contribution of the earthquakes, crustal blocks model. Geophys. J. Int. 2021, 226, 468-492. [CrossRef]

42. Sakellariou, D.; Tsampouraki-Kraounaki, K. Plio-Quaternary Extension and Strike-Slip Tectonics in the Aegean. In Transform Plate Boundaries and Fracture Zones; Elsevier: Amsterdam, The Netherlands, 2019; pp. 339-374.

43. Mascle, J.; Martin, L. Shallow structure and recent evolution of the Aegean Sea: A synthesis based on continuous reflection profiles. Mar. Geol. 1990, 94, 271-299. [CrossRef] 
44. Pavlides, S.; Tranos, M. Structural characteristics of two strong earthquakes in the North Aegean: Ierissos (1932) and Agios Efstratios (1968). J. Struct. Geol. 1991, 13, 205-214. [CrossRef]

45. Müller, M.; Geiger, A.; Kahle, H.-G.; Veis, G.; Billiris, H.; Paradissis, D.; Felekis, S. Velocity and deformation fields in the North Aegean domain, Greece, and implications for fault kinematics, derived from GPS data 1993-2009. Tectonophysics 2013, 597-598, 34-49. [CrossRef]

46. Kahle, H.-G.; Cocard, M.; Peter, Y.; Geiger, A.; Reilinger, R.; McClusky, S.; King, R.; Barka, A.; Veis, G. The GPS strain rate field in the Aegean Sea and western Anatolia. Geophys. Res. Lett. 1999, 26, 2513-2516. [CrossRef]

47. Tur, H.; Yaltırak, C.; Elitez, I.; Sarıkavak, K.T. Pliocene-Quaternary tectonic evolution of the Gulf of Gökova, southwest Turkey. Tectonophysics 2015, 638, 158-176. [CrossRef]

48. Bohnhoff, M.; Rische, M.; Meier, T.; Becker, D.; Stavrakakis, G.; Harjes, H.-P. Microseismic activity in the Hellenic Volcanic Arc, Greece, with emphasis on the seismotectonic setting of the Santorini-Amorgos zone. Tectonophysics 2006, 423, 17-33. [CrossRef]

49. Pe-Piper, G.; Piper, D.J.; Perissoratis, C. Neotectonics and the Kos Plateau Tuff eruption of 161 ka, South Aegean arc. J. Volcanol. Geotherm. Res. 2005, 139, 315-338. [CrossRef]

50. Uluğ, A.; Duman, M.; Ersoy, Ş.; Özel, E.; Avc1, M. Late Quaternary sea-level change, sedimentation and neotectonics of the Gulf of Gökova: Southeastern Aegean Sea. Mar. Geol. 2005, 221, 381-395. [CrossRef]

51. Işcan, Y.; Tur, H.; Gökaşan, E. Morphologic and seismic features of the Gulf of Gökova, SW Anatolia: Evidence of strike-slip faulting with compression in the Aegean extensional regime. Geo-Mar. Lett. 2012, 33, 31-48. [CrossRef]

52. Ocakoğlu, N.; Nomikou, P.; Işcan, Y.; Loreto, M.F.; Lampridou, D. Evidence of extensional and strike-slip deformation in the offshore Gökova-Kos area affected by the July 2017 Mw6.6 Bodrum-Kos earthquake, eastern Aegean Sea. Geo-Mar. Lett. 2018, 38, 211-225. [CrossRef]

53. Bornovas, J.; Rondoyanni, T. Geological map of Greece, scale 1:500.000. Inst. Geol. Min. Explor. Greece 1984.

54. Nomikou, P.; Hübscher, C.; Papanikolaou, D.; Farangitakis, G.; Ruhnau, M.; Lampridou, D. Expanding extension, subsidence and lateral segmentation within the Santorini-Amorgos basins during Quaternary: Implications for the 1956 Amorgos events, central-south Aegean Sea, Greece. Tectonophysics 2018, 722, 138-153. [CrossRef]

55. Kilias, S.P.; Nomikou, P.; Papanikolaou, D.; Polymenakou, P.N.; Godelitsas, A.; Argyraki, A.; Carey, S.; Gamaletsos, P.; Mertzimekis, T.J.; Stathopoulou, E.; et al. New insights into hydrothermal vent processes in the unique shallow-submarine arc-volcano, Kolumbo (Santorini), Greece. Sci. Rep. 2013, 3, 1-13. [CrossRef] [PubMed]

56. Melidonis, N.G. The Geology of Anafi island. Ph.D. Thesis, Aristotle University of Thessaloniki, Boulder, CO, USA, 1964; 308p.

57. Fytrolakis, N.; Papanikolaou, D. Stratigraphy and structure of Amorgos Island, Aegean Sea. Ann. Geol. Pays Hellen. 1981 30, 455-472.

58. Papanikolaou, D. Tectonostratigraphic models of the Alpine terranes and subduction history of the Hellenides. Tectonophysics 2013, 595-596, 1-24. [CrossRef]

59. Papadopoulos, G.A.; Pavlides, S.B. The large 1956 earthquake in the South Aegean: Macroseismic field configuration, faulting, and neotectonics of Amorgos Island. Earth Planet. Sci. Lett. 1992, 113, 383-396. [CrossRef]

60. Soukis, K.; Papanikolaou, D. Contrasting geometry between alpine and late- to post- alpine tectonic structures in Anafi Island (Cyclades). Bull. Geol. Soc. Greece 2004, 36, 1688-1696. [CrossRef]

61. Perissoratis, C. The Santorini volcanic complex and its relation to the stratigraphy and structure of the Aegean arc, Greece. Mar Geol. 1995, 128, 37-58. [CrossRef]

62. Nomikou, P.; Hubscher, C.; Ruhnau, M.; Bejelou, K. Tectono-stratigraphic evolution through successive extensional events of the Anydros Basin, hosting Kolumbo volcanic field at the Aegean Sea, Greece. Tectonophysics 2016, 671, 202-217. [CrossRef]

63. Hooft, E.E.; Nomikou, P.; Toomey, D.R.; Lampridou, D.; Getz, C.; Christopoulou, M.-E.; O’Hara, D.; Arnoux, G.M.; Bodmer, M.; Gray, M.; et al. Backarc tectonism, volcanism, and mass wasting shape seafloor morphology in the Santorini-Christiana-Amorgos region of the Hellenic Volcanic Arc. Tectonophysics 2017, 712-713, 396-414. [CrossRef]

64. Sakellariou, D.; Sigurdsson, H.; Alexandri, M.; Carey, S.; Rousakis, G.; Nomikou, P.; Georgiou, P.; Ballas, D. Active Tectonics in the Hellenic Volcanic Arc: The Kolumbo Submarine Volcanic Zone. Bull. Geol. Soc. Greece 2017, 43, 1056. [CrossRef]

65. Hübscher, C.; Ruhnau, M.; Nomikou, P. Volcano-tectonic evolution of the polygenetic Kolumbo submarine volcano/Santorini (Aegean Sea). J. Volcanol. Geotherm. Res. 2015, 291, 101-111. [CrossRef]

66. Piper, D.; Perissoratis, C. Quaternary neotectonics of the South Aegean arc. Mar. Geol. 2003, 198, 259-288. [CrossRef]

67. Hsu, K.J.; Montadert, L.; Bernouilli, D.; Bizon, G.; Cita, M.; Erickson, A.; Fabricius, F.; Garrison, R.E.; Kido, R.B.; Mellieres, F.; et al. Site 378: Cretan basin. Init. Rep. Deep-Sea Drill. Proj. 1978, 42, 321-357.

68. Smith, P.E.; York, D.; Chen, Y.; Evensen, N.M. Single crystal40Ar-39Ar dating of a Late Quaternary paroxysm on Kos, Greece: Concordance of terrestrial and marine ages. Geophys. Res. Lett. 1996, 23, 3047-3050. [CrossRef]

69. Van Hinsbergen, D.J.; Krijgsman, W.; Langereis, C.G.; Cornée, J.-J.; Duermeijer, C.E.; Van Vugt, N. Discrete Plio-Pleistocene phases of tilting and counterclockwise rotation in the southeastern Aegean arc (Rhodos, Greece): Early Pliocene formation of the south Aegean left-lateral strike-slip system. J. Geol. Soc. 2007, 164, 1133-1144. [CrossRef]

70. Perissoratis, C.; Andrinopoulos, A.; Zacharaki, P.; Zimianitis, E. Sedimentological and geological studies in the middle part of the South Aegean Arc: Preliminary results. Bull. Geol. Soc. Greece 1993, 28, 511-531.

71. Piper, D.J.W.; Pe-Piper, G.; Perissoratis, C.; Anastasakis, G. Distribution and chronology of submarine volcanic rocks around Santorini and their relationship to faulting. Geol. Soc. Lond. Spec. Publ. 2007, 291, 99-111. [CrossRef] 
72. Heath, B.A.; Hooft, E.E.E.; Toomey, D.R.; Papazachos, C.B.; Nomikou, P.; Paulatto, M.; Morgan, J.V.; Warner, M.R. Tectonism and Its Relation to Magmatism Around Santorini Volcano from Upper Crustal P Wave Velocity. J. Geophys. Res. Solid Earth 2019, 124, 10610-10629. [CrossRef]

73. Tsampouraki-Kraounaki, K.; Sakellariou, D. Strike-slip deformation behind the Hellenic subduction: The Amorgos Shear Zone, South Aegean Sea. In Proceedings of the 8th Internation-al INQUA Meeting on Paleoseismology, Active Tectonics and Archeoseismology, Blenheim, New Zeeland, 13-16 November 2017; Clark, K.J., Upton, P., Langridge, R., Kelly, K., Hammond, K., Eds.; pp. 392-395. [CrossRef]

74. Dimitriadis, I.; Karagianni, E.; Panagiotopoulos, D.; Papazachos, C.; Hatzidimitriou, P.; Bohnhoff, M.; Rische, M.; Meier, T. Seismicity and active tectonics at Coloumbo Reef (Aegean Sea, Greece): Monitoring an active volcano at Santorini Volcanic Center using a temporary seismic network. Tectonophysics 2009, 465, 136-149. [CrossRef]

75. Dimitriadis, I.; Papazachos, C.; Panagiotopoulos, D.; Hatzidimitriou, P.; Bohnhoff, M.; Rische, M.; Meier, T. P and S velocity structures of the Santorini-Coloumbo volcanic system (Aegean Sea, Greece) obtained by non-linear inversion of travel times and its tectonic implications. J. Volcanol. Geotherm. Res. 2010, 195, 13-30. [CrossRef]

76. Papadimitriou, P.; Kapetanidis, V.; Karakonstantis, A.; Kaviris, G.; Voulgaris, N.; Makropoulos, K. The Santorini Volcanic Complex: A detailed multi-parameter seismological approach with emphasis on the 2011-2012 unrest period. J. Geodyn. 2015, 85, 32-57. [CrossRef]

77. Tsampouraki-Kraounaki, K.; Sakellariou, D. Seismic stratigraphy and geodynamic evolution of Christiana Basin, South Aegean Arc. Mar. Geol. 2018, 399, 135-147. [CrossRef]

78. Tzanis, A.; Chailas, S.; Sakkas, V.; Lagios, E. Tectonic deformation in the Santorini volcanic complex (Greece) as inferred by joint analysis of gravity, magnetotelluric and DGPS observations. Geophys. J. Int. 2020, 220, 461-489. [CrossRef]

79. Okal, E.A.; Synolakis, C.E.; Uslu, B.; Kalligeris, N.; Voukouvalas, E. The 1956 earthquake and tsunami in Amorgos, Greece. Geophys. J. Int. 2009, 178, 1533-1554. [CrossRef]

80. Shirokova, E.I. Napryazheniya i Razryvy v Ochagakh Zemletryasenii Sredizemnomorskovo-Aziatskovo Seismicheskovo Poyasa, in Polye upRugikh Napryazhenii Zemli i Mekhanizm Ochagov Zemletryasenii; Balakina, L.M., Vvedenskaya, A.V., Golubeva, N.V., Misharina, L.A., Shirokova, E.I., Eds.; Akad. Nauk SSSR: Moskow, Russia, 1972; pp. 112-148. (In Russian)

81. Papazachos, B.; Delibasis, N. Tectonic stress field and seismic faulting in the area of Greece. Tectonophysics 1969, 7, $231-255$. [CrossRef]

82. Ritsema, A.R. Earthquake mechanisms of the Balkan region, Kon. Ned. Meteor. Inst. Repts. 1974, 74, 36.

83. Brüstle, A.; Friederich, W.; Meier, T.; Gross, C. Focal mechanism and depth of the 1956 Amorgos twin earthquakes from waveform matching of analogue seismograms. Solid Earth 2014, 5, 1027-1044. [CrossRef]

84. Alexandri, M.; Papanikolaou, D.; Nomikou, P.; Ballas, D. Santorini Volcanic Field-New Insights Based on Swath Bathymetry; Abstracts IUGG: Saporo, Japan, 2003.

85. Sigurdsson, H.; Carey, S.; Alexandri, M.; Vougioukalakis, G.; Croff, K.L.; Roman, C.; Sakellariou, D.; Anagnostou, C.; Rousa-kis, G.; Ioakim, C. Marine investigations of Greece's Santorini volcanic field. Eos 2006, 87, 337-339. [CrossRef]

86. Nomikou, P.; Papanikolaou, D. Extension of active fault zones on Nisyros volcano across the Yali-Nisyros Channel based on onshore and offshore data. Mar. Geophys. Res. 2011, 32, 181-192. [CrossRef]

87. Nomikou, P.; Carey, S.; Papanikolaou, D.; Bell, K.C.; Sakellariou, D.; Alexandri, M.; Bejelou, K. Submarine volcanoes of the Kolumbo volcanic zone NE of Santorini Caldera, Greece. Glob. Planet. Chang. 2012, 90-91, 135-151. [CrossRef]

88. Frey-Martinez, J. 3D Seismic Interpretation of Mass Transport Deposits: Implications for Basin Analysis and Geohazard Evaluation. Submar. Mass Mov. Conseq. 2007, 28, 553-568. [CrossRef]

89. Bartole, R.; Catani, G.; Lenardon, G.; Vinci, A. Tectonics and sedimentation of the Southern Aegean Sea. Boll. Oceanol. Teor. Appl. 1983, 4, 319-340.

90. Anastasakis, G.; Piper, D.J. Late Neogene evolution of the western South Aegean volcanic arc: Sedimentary imprint of volcanicity around Milos. Mar. Geol. 2005, 215, 135-158. [CrossRef]

91. Withjack, M.O.; Jamison, W.R. Deformation produced by oblique rifting. Tectonophysics 1986, 126, 99-124. [CrossRef]

92. Stiros, S.C.; Marangou, L.; Arnold, M. Quaternary uplift and tilting of Amorgos Island (Southern Aegean) and the 1956 earthquake. Earth Planet. Sci. Lett. 1994, 128, 65-76. [CrossRef]

93. Galanopoulos, A.G. The seismic sea wave of 9 July 1956. Prakt. Akad. Athens 1957, 32, 90-101.

94. Ambraseys, N.N. The seismic sea wave of July 9, 1956, in the Greek archipelago. J. Geophys. Res. Space Phys. 1960, 65, 1257-1265. [CrossRef]

95. Papazachos, B.; Koutitas, C.; Hatzidimitriou, P.; Karacostas, B.; Papaioannou, C. Source and short-distance propagation of the July 9, 1956 southern Aegean tsunami. Mar. Geol. 1985, 65, 343-351. [CrossRef]

96. Papadopoulos, G.A.; Gràcia, E.; Urgeles, R.; Sallares, V.; De Martini, P.M.; Pantosti, D.; González, M.; Yalciner, A.C.; Mascle, J.; Sakellariou, D.; et al. Historical and pre-historical tsunamis in the Mediterranean and its connected seas: Geological signatures, generation mechanisms and coastal impacts. Mar. Geol. 2014, 354, 81-109. [CrossRef]

97. Konstantinou, K. Crustal rheology of the Santorini-Amorgos zone: Implications for the nucleation depth and rupture extent of the 9 July 1956 Amorgos earthquake, southern Aegean. J. Geodyn. 2010, 50, 400-409. [CrossRef]

98. Rossi, S.; Got, H.; Taviani, M.; Martin, L. Elements structuraux de la mer de Crete orientale et du Golfe d'Antalya (Medi-terranee orientale). Mem. Soc. Geol. It. 1986, 36, 153-164. 
99. Royden, L.H. The tectonic expression slab pull at continental convergent boundaries. Tectonics 1993, 12, 303-325. [CrossRef]

100. Jolivet, L.; Faccenna, C. Mediterranean extension and the Africa-Eurasia collision. Tectonics 2000, 19, 1095-1106. [CrossRef]

101. Faccenna, C.; Jolivet, L.; Piromallo, C.; Morelli, A. Subduction and the depth of convection in the Mediterranean mantle. J. Geophys. Res. Space Phys. 2003, 108. [CrossRef]

102. Faccenna, C.; Becker, T.W.; Auer, L.; Billi, A.; Boschi, L.; Brun, J.P.; Capitanio, F.A.; Funiciello, F.; Horvàth, F.; Jolivet, L.; et al. Mantle dynamics in the Mediterranean. Rev. Geophys. 2014, 52, 283-332. [CrossRef]

103. Brun, J.-P.; Faccenna, C. Exhumation of high-pressure rocks driven by slab rollback. Earth Planet. Sci. Lett. $2008,272,1-7$. [CrossRef]

104. Brun, J.-P.; Sokoutis, D. 45 m.y. of Aegean crust and mantle flow driven by trench retreat. Geology 2010, 38, 815-818. [CrossRef]

105. Jolivet, L.; Brun, J.-P. Cenozoic geodynamic evolution of the Aegean. Acta Diabetol. 2008, 99, 109-138. [CrossRef]

106. Beniest, A.; Brun, J.-P.; Gorini, C.; Crombez, V.; Deschamps, R.; Hamon, Y.; Smit, J. Interaction between trench retreat and Anatolian escape as recorded by neogene basins in the northern Aegean Sea. Mar. Pet. Geol. 2016, 77, 30-42. [CrossRef]

107. Le Pichon, X.; Şengör, A.C.; Kende, M.J.; Imren, C.; Henry, P.; Grall, C.; Karabulut, H. Propagation of a strike-slip plate boundary within an extensional environment: The westward propagation of the North Anatolian Fault. Can. J. Earth Sci. 2016, 53, 1416-1439. [CrossRef]

108. Ferentinos, G.; Georgiou, N.; Christodoulou, D.; Geraga, M.; Papatheodorou, G. Propagation and termination of a strike slip fault in an extensional domain: The westward growth of the North Anatolian Fault into the Aegean Sea. Tectonophysics 2018, 745, 183-195. [CrossRef] 